\title{
Immune Checkpoints Pathways in Head and Neck Squamous Cell Carcinoma
}

\author{
Florencia Veigas ${ }^{1}$, Yamil D. Mahmoud ${ }^{1}{ }^{(}$, Joaquin Merlo ${ }^{1}{ }^{(0)}$, Adriana Rinflerch ${ }^{2}$, Gabriel Adrian Rabinovich ${ }^{3,4}$ \\ and María Romina Girotti ${ }^{1, *}$
}

1 Laboratorio de Inmuno Oncología Traslacional, Instituto of Biología y Medicina Experimental, Consejo Nacional de Investigaciones Científicas y Técnicas (CONICET), Buenos Aires C1428ADN, Argentina; fveigas@dna.uba.ar (F.V.); ymahmoud@dna.uba.ar (Y.D.M.); jmerlo@dna.uba.ar (J.M.)

2 Laboratorio GIGA, Facultad de Ciencias Exactas, Químicas y Naturales, Instituto de Biología Subtropical, Universidad Nacional de Misiones, CONICET, Posadas N3300NFK, Misiones, Argentina; adriana.rinflerch@hospitalitaliano.edu.ar

3 Laboratorio de Inmunopatología, Instituto of Biología y Medicina Experimental, CONICET, Buenos Aires C1428ADN, Argentina; gabriel.r@ibyme.conicet.gov.ar

4 Facultad de Ciencias Exactas y Naturales, Universidad de Buenos Aires, Buenos Aires C1428EGA, Argentina

* Correspondence: mgirotti@dna.uba.ar

\section{check for} updates

Citation: Veigas, F.; Mahmoud, Y.D.; Merlo, J.; Rinflerch, A.; Rabinovich,

G.A.; Girotti, M.R. Immune

Checkpoints Pathways in Head and Neck Squamous Cell Carcinoma.

Cancers 2021, 13, 1018.

https://doi.org/10.3390/

cancers 13051018

\section{Academic Editors:}

Francesco Cavallin, Marco Scarpa and Myung-Ju Ahn

Received: 7 January 2021

Accepted: 25 February 2021

Published: 1 March 2021

Publisher's Note: MDPI stays neutral with regard to jurisdictional claims in published maps and institutional affiliations.

Copyright: (c) 2021 by the authors. Licensee MDPI, Basel, Switzerland. This article is an open access article distributed under the terms and conditions of the Creative Commons Attribution (CC BY) license (https:/ / creativecommons.org/licenses/by/ $4.0 /)$.
Simple Summary: During the last decades, scientific advances in immuno-oncology and a better understanding of tumors' immune profile led to the development of novel immunotherapeutic strategies, especially immune checkpoint inhibitors. The blockade of PD-1 by monoclonal antibodies (mAbs) is the only immunotherapy based on immune checkpoint pathways approved for head and neck squamous cell carcinoma. As only a small fraction of patients perceives clinical benefit, understanding the molecular mechanisms and signaling pathways activated by the immune checkpoints and other tumor intrinsic features that modulate the immune infiltrate is crucial to better select patients for immunotherapy treatment and to develop novel therapeutic strategies. We here review the immune escape mechanisms of head and neck tumors, with a particular focus on the immune checkpoints, their role as therapeutic targets, and the predictive biomarkers of response to anti-PD-1/PD-L1 therapy. We also summarize the ongoing clinical trials testing several combinations of immune checkpoint inhibitors with other therapeutic approaches to improve patient outcomes.

Abstract: Head and neck squamous cell carcinoma (HNSCC) is a heterogeneous group of tumors usually diagnosed at an advanced stage and characterized by a poor prognosis. The main risk factors associated with its development include tobacco and alcohol consumption and Human Papillomavirus (HPV) infections. The immune system has a significant role in the oncogenesis and evolution of this cancer type. Notably, the immunosuppressive tumor microenvironment triggers immune escape through several mechanisms. The improved understanding of the antitumor immune response in solid tumors and the role of the immune checkpoint molecules and other immune regulators have led to the development of novel therapeutic strategies that revolutionized the clinical management of HNSCC. However, the limited overall response rate to immunotherapy urges identifying predictive biomarkers of response and resistance to treatment. Here, we review the role of the immune system and immune checkpoint pathways in HNSCC, the most relevant clinical findings linked to immunotherapeutic strategies and predictive biomarkers of response and future treatment perspectives.

Keywords: immune infiltrate; head and neck cancer; immunotherapy; immune checkpoint

\section{Introduction}

Head and neck cancers comprise a heterogeneous group of tumors arising in the head and neck region, with head and neck squamous cell carcinoma being the most frequent 
histology type. Particularly, HNSCC develops in the mucosal surfaces lining the paranasal sinuses, nasal and oral cavity, oropharynx, larynx, and hypopharynx [1]. HNSCC is the sixth most common cancer worldwide, and its incidence continues to rise [2]. By 2020, the number of new cases and deaths estimated worldwide was more than 800,000 and 400,000, respectively [3].

The main risk factors for developing HNSCC are tobacco smoke, alcohol consumption, and HPV infections [4-6]. HPV-positive $\left(\mathrm{HPV}^{+}\right)$cancers often arise in the oropharynx cavity and represent a different biological and clinical entity with a distinct mutation landscape characterized by markedly improved survival $[7,8]$. The genomic landscape of HNSCC is characterized by tumor heterogeneity and loss-of-function mutations in tumor-suppressor genes such as TP53 and FAT1, activation of oncogenes such as EGFR and PIK3CA, or inactivation by heterozygous and homozygous losses in CDKN2A (reviewed in Reference [8]). Interestingly, TP53 and CDKN2A, most frequently altered in HNSCC, are unaffected in $\mathrm{HPV}^{+}$tumors, which are characterized by molecular alterations in the PI3K pathway [8].

The initial diagnosis of HNSCC is often clinical and is based on the patient's symptoms that vary from chronic pain in the throat, tongue, or mouth to hoarseness or difficulty swallowing. Clinical examination of the head and neck is a major for HNSCC diagnosis as these patients could present non-healing ulcers, red/white patches in the mouth, or an irregular mass in the neck. Pathological confirmation of the diagnosis by analysis of a tumor biopsy is mandatory [1,9]. The microscopic appearance may vary as a function of tumor differentiation, and the main neoplastic alteration includes abnormal cellular organization, increased mitotic activity, and nuclear enlargement with pleomorphism [10]. The increasing incidence of HPV-associated HNSCC and its relevant role as a prognostic biomarker in oropharyngeal squamous cell carcinomas (OSCC) supports the molecular testing for HPV infection in all patients diagnosed with this HNSCC subtype. Current guidelines indicate the routine pathological evaluation of HPV in (1) newly diagnosed OSCC patients from the primary tumor or cervical nodal metastases by p16 immunohistochemistry (IHC), any additional HPV testing should be performed at the discretion of the pathologist or treating physician, and (2) patients with metastatic unknown primary from cervical upperor mid-jugular chain lymph node by $\mathrm{p} 16 \mathrm{IHC}$ and then for $\mathrm{p} 16^{+}$tumors, HPV-specific detection assays must be done to confirm HPV status [11].

HNSCC subtypes are clinically, histologically, and molecularly distinct, and their treatment is mainly guided by the specific site of disease, size, age, tumor accessibility, performance status, and stage and is not based on genomic alterations or gene expression profiles. The NCCN and ESMO guidelines report that patients with early-stage tumors are recommended to be treated by a single arm-modality with either surgery or radiotherapy (RT), often providing similar survival rates or locoregional control. However, each case should be evaluated individually, as one modality may be better than the other under certain conditions. Particularly, the treatment is uniform within each HNSCC entity, being surgery usually preferred for oral cavity and paranasal sinus, and RT for nasopharyngeal carcinomas. Nevertheless, the choice of treatment modality should be based on the assessment of functional outcomes and perceived relative morbidity for each patient as well as institutional and patient preferences and experience $[9,12]$. Usually, early-stage cancers have a favorable prognosis with high cure rates, and the treatment improves long-term survival. However, patients with locally advanced HNSCC cancer carry a high risk of recurrence, distant metastases, and poor prognosis [1]. For locoregional advanced HNSCC, standard treatment often includes surgery plus adjuvant RT, or chemoradiotherapy (CRT), or primary CRT alone. Generally, surgery is preferred for the oral cavity followed by RT or CRT, while for other sites, surgery is reserved for smaller accessible primary tumors or for those whose response to induction CRT was poor. Particularly, concomitant CRT resulted in greater locoregional control and improved OS than RT alone, irrespective of the tumor location. Nonetheless, treatment decisions need to be individualized and carefully evaluated by a multispecialty team in a tumor board and several aspects should be con- 
sidered: morbidity, toxic effects, and preservation of organ function, among others $[9,12]$. However, around $50 \%$ of patients with locally advanced HNSCC develop recurrence after primary treatment with metastatic, local, or regional disease and have a poor prognosis with a median overall survival (OS) under 12 months (six to nine months without treatment) [1]. Treatment of these patients is complex and requires the evaluation of tumor- and patient-related factors for selecting the optimal combination and sequencing of treatments. Patients with locoregional recurrence may be candidates for surgical salvage, and those patients not amenable to surgery are candidates for curative-intent RT or re-irradiation with or without chemotherapy depending on the time since prior treatment and related toxicity. On the other hand, for patients with recurrent or metastatic (R/M) HNSCC not amenable to the mentioned curative options, palliative systemic therapy is indicated [13]. In this regard, the standard of care (SoC) in the first-line setting from 2008 to 2019 has been the EXTREME regimen, consisting of platinum-based doublet chemotherapy with cetuximab and 5-fluorouracil while for second-line treatment until 2016 has been cetuximab, methotrexate, and taxane [14].

Over the last few years, a revolution started with the development and approval of immunomodulatory therapies, particularly Immune Checkpoint Blockade (ICB) therapies, for patients with R/M HNSCC. In 2020, the current FDA indications for Pembrolizumab treatment in HNSCC were as follows: (1) in combination with platinum and 5-fluorouracil for the first-line treatment of patients with metastatic or with unresectable, recurrent HNSCC; (2) as a single agent for the first-line treatment of patients with metastatic or with unresectable, recurrent HNSCC whose tumors express Programmed Death-Ligand 1 (PD-L1) (Combined Positive Score (CPS): $\geq 1$ ) as determined by an FDA-approved test; (3) as a single agent for the treatment of patients with R/M HNSCC with disease progression on or after platinum-containing chemotherapy [15]. As with other tumor types, molecular biomarkers are critical for diagnosis, monitoring disease progression, and predicting response to treatment. Currently, only PD-L1 expression is widely used as a predictive biomarker for response to immune checkpoint inhibitors in HNSCC [16]. Indeed, current guidelines recommend the evaluation of PD-L1 in HNSCC tumors by IHC. Concerning $\mathrm{HPV}$ status, despite its prognostic value in OSCC patients, it does not change the treatment algorithm $[9,12]$. However, clinical differences between $\mathrm{HPV}^{+}$and $\mathrm{HPV}^{-}$patients are now being tested separately in several ongoing or just finished clinical trials to evaluate biological and treatment-related questions such as how HPV status impacts tumor response to treatment and de-escalation of the standard therapy for $\mathrm{HPV}^{+}$tumors $[17,18]$. Deescalation aims to decrease toxicity and morbidity resulted from $\mathrm{SoC}$, while maintaining tumor control, quality of life, and favorable survival [18]. Likewise, EGFR overexpression and specific TP53 in HNSCC are associated with poor survival outcomes but do not impact treatment algorithms [14,19]. Many biomarkers have been suggested to impact the diagnosis and prognosis of HNSCC, significantly. However, they still lack high specificity and sensitivity, low cost, high positive predictive value, clinical relevance, and short turnaround time $[20,21]$.

This review revises the immune escape mechanisms in HNSCC, focusing on the immune checkpoint pathways and their role as therapeutic targets. Furthermore, we discuss the use of Immune Checkpoint Blockade (ICB) in HNSCC treatment, the ongoing clinical trials testing several combinations of immune checkpoint inhibitors with other therapeutic approaches, and novel predictive biomarkers of response to anti-PD-1/PD-L1 therapy.

\section{Mechanisms of Immune Escape in HNSCC}

HNSCC is considered an immunogenic tumor as it is often accompanied by a prominent immune infiltrate [22]. However, this infiltrate leads to impaired tumor recognition and elimination, given its immunosuppressive nature [23]. Tumor-immune escape, orchestrated by cellular and molecular regulatory networks, represents a key hallmark of cancer, generating a microenvironment permissive for tumor survival, progression, and treatment 
failure [24]. Understanding the mechanisms implicated in immune evasion is crucial to better select patients for immunotherapy treatment and develop novel therapeutic strategies. The main mechanisms underlying immune escape in HNSCC are alterations in the antigen presentation machinery and the composition and activation profile of tumor-infiltrating immune cells shifting the tumor microenvironment (TME) towards more permissive for tumor progression (reviewed in Reference [23]).

\subsection{Composition and Activation Profile of Immune Cells in the TME}

The TME is a complex network composed of different cell types and soluble factors like chemokines, cytokines, and growth factors. Immune cells, including $\mathrm{CD} 4^{+}$and $\mathrm{CD} 8^{+} \mathrm{T}$ cells, regulatory T cells (Tregs), tumor-associated macrophages (TAMs), and myeloid-derived suppressor cells (MDSCs) are the main immune cells frequently infiltrating tumors [25], including HNSCC.

Several studies have shown that $\mathrm{T}$ cells of HNSCC patients are poorly responsive to antigenic stimuli, have an altered cytokine profile, show low cytotoxic activity, and have impaired signaling via T cell receptor (TCR), favoring immune-escape [26-29]. In HNSCC patients, there is also a decrease in the absolute $\mathrm{T}$ cell count in both tumor and circulation, an effect possibly related to spontaneous apoptosis via Fas/FasL pathway [30]. A systematic review and meta-analysis proposed that the infiltration of $\mathrm{CD} 8^{+} \mathrm{T}$ cells has a favorable prognostic value in HNSCC patients, while $\mathrm{CD}^{+}{ }^{+} \mathrm{T}$ cells' role remains questionable [31]. Moreover, Tregs contribute to immunosuppression in HNSCC by secreting IL-10 and TGF$\beta 1$ to the TME, hindering the antitumor activity of effector T cells (Teff) [32-34]. Although Tregs in the TME and circulation of HNSCC patients overexpress immune checkpoints on their surface, infiltrating Tregs are more immunosuppressive [35]. Depending on the cancer type, Tregs have been associated with either poor or good clinical outcomes. In particular, for HNSCC is still controversial, and evidence in the literature supports the notion that Tregs are associated with enhanced progression-free survival (PFS) and OS [31,36-38].

MDSCs and TAMs stand out as the most immunosuppressive tumor-infiltrating cells. On the one hand, MDSCs dampen immune responses by inhibiting Teff cells' functions, fostering Tregs, and polarizing macrophages towards a pro-tumoral phenotype in the TME. In HNSCC patients, an inflammatory infiltrate with a predominant granulocytic MDSCs profile is associated with poorer survival [39]. Moreover, a recent study demonstrated that MDSCs infiltrating these tumors exhibit greater immunosuppressive capacity than those in circulation through several mechanisms involving TGF- $\beta 1$ and nitric oxide [40]. On the other hand, macrophages could be categorized as classically activated (M1) or alternatively activated (M2) macrophages. Whereas M1 macrophages express proinflammatory mediators, promote activation of cytotoxic $\mathrm{CD} 8^{+} \mathrm{T}$ cells, and foster antitumoral immune response, M2 macrophages induce angiogenesis, tissue remodeling, immune escape, and stimulate Treg cell differentiation by expression of immunosuppressive cytokines [41]. TAMs are recruited to the TME by different cytokines and often create a favorable milieu for tumor survival by suppressing immune responses. As in other malignancies, TAMs in HNSCC promote metastasis by inducing stemness and epithelial-mesenchymal transition (EMT) [42]. Indeed, two different meta-analyses showed that an infiltrate composed of a high number of $\mathrm{CD} 163^{+}$TAMs (M2-like) is associated with worse OS and PFS accompanied by poor cell differentiation and advanced disease status $[43,44]$. The aberrant activation of the STAT3 signaling pathway in HNSCC is associated with the infiltration of M2-like TAMs and MDSCs in the TME [45].

\subsection{Development of a Tumor-Promoting Microenvironment}

The TME comprises several cell types and a network of soluble factors that orchestrate the immunosuppressive microenvironment. Particularly, the TME in HNSCC is enriched in immune inhibitory molecules that can directly thwart host immunity, impacting survival or altering the function of immune cells [46-48]. Tumor-infiltrating Tregs are the primary source of both TGF- $\beta 1$ and IL-10 [32,33]. While TGF- $\beta 1$ significantly contributes to immune 
dysfunction in HNSCC, attenuating the activity of Teff cells and promoting the expansion of infiltrating Tregs (reviewed by Reference [49]), IL-10 is strongly associated with disease progression [50]. This cytokine exerts anti-inflammatory properties by favoring the recruitment and activity of other immunosuppressive cells.

The pleiotropic proinflammatory cytokine IL-6 can independently predict tumor recurrence, poor survival, and tumor metastasis in HNSCC [51]. Moreover, a recent study showed the association between IL-6 levels, survival, and immunosuppression. Notably, Tsai and colleagues observed that IL-6 upregulates PD-L1 expression and MDSCs infiltration in HNSCC tumors [52].

Bergmann and colleagues showed that prostaglandin-E2 (PGE2), a soluble product of cyclooxygenase-2 (COX-2) activity, is implicated in tumor immunosuppression in HNSCC, promoting the expansion of Tregs [53]. Interestingly, COX-2 expression was increased in HNSCC tumor biopsies compared to paired-normal tissue [54]. Therapeutic attempts to block PGE2-mediated immunosuppression in vivo using COX-2 inhibitors in a mouse model of HNSCC induced antitumor effects and restored antitumor immunity [55], thus highlighting its relevant role in immune escape. Additionally, COX-2 expression was higher in metastatic lesions and significantly correlated with tumor vascularization [56]. VEGF, a regulatory cytokine implicated in angiogenesis and vascularization, is also overexpressed in HNSCC tumors and is associated with poor prognosis [57].

\subsection{Galectin-1 as a Soluble Immune Checkpoint}

Galectin 1 (Gal-1) has been proposed as a novel immune checkpoint involved in different cancer hallmarks. In human tissue of HNSCC, Gal-1 overexpression has been associated with lower infiltration of $\mathrm{T}$ cells and was identified as an independent prognostic factor for shorter OS [58]. Interestingly, the presence of Gal-1 in tumor-associated exosomes secreted by head and neck cancer cell lines induced a marked suppression of CD8 ${ }^{+} \mathrm{T}$ cell activity. This suppressive effect was characterized by the loss of CD27/CD28 costimulatory molecules and the decrease of IFN- $\gamma$ production, in accordance with the phenotype presented by T cells on HNSCC tumor biopsies [59]. Further studies in a mouse model of HNSCC, showed that this lectin generates an immunosuppressive barrier that prevents $\mathrm{T}$ cell migration to the tumor, particularly by up-regulation of immune-inhibitory ligands including PD-L1 and Galectin-9 (Gal-9). In this regard, Gal-1 in this preclinical model improved the effect of anti-PD-1 immunotherapy. Accordingly, lower levels of Gal-1 in the tumor and stroma were associated with better response to anti-PD-1 therapy and higher survival rates in HNSCC patients with R/M disease [60]. Based on this evidence, Gal-1 has been proposed as a prognostic biomarker and a promising therapeutic target in HNSCC (Figure 1).

\subsection{Alteration in the Antigen Presentation Machinery (APM)}

One of the requirements for antitumor immunity is $\mathrm{T}$ cell recognition of tumor antigen peptides presented by the major histocompatibility complex (MHC), also known in humans as human leukocyte antigen (HLA), on the surface of tumor cells or antigen-presenting cells (APCs), a process known as antigen presentation. There are two classes of MHC molecules, the MHC class I proteins, which take part in antigen presentation to $\mathrm{CD} 88^{+} \mathrm{T}$ cells, and the MHC class II proteins, involved in antigen presentation to $\mathrm{CD} 4^{+} \mathrm{T}$ cells. Although immunogenic tumor antigens occur in HNSCC, in some cases they may not be recognized by $T$ cells and trigger immune responses. In general, cells with complete loss of HLA evade $\mathrm{T}$ cell response but can trigger an immune response by natural killer (NK) cells. However, tumor cells may use different mechanisms to downregulate HLA expression to avoid recognition by NK or T cells. In this regard, the genomic and transcriptomic sequencing of HNSCC tumors revealed multiple mutations in HLA alleles and APM components [61]. Moreover, the downregulation of HLA class I antigen and LMP2 (a component of the $\mathrm{APM}$ ) correlates with low $\mathrm{CD}^{+} \mathrm{T}$ cell infiltration and is significantly associated with 
lower survival rates in HNSCC patients [62], similar to other AMP components which are associated with poor clinical outcome [63].

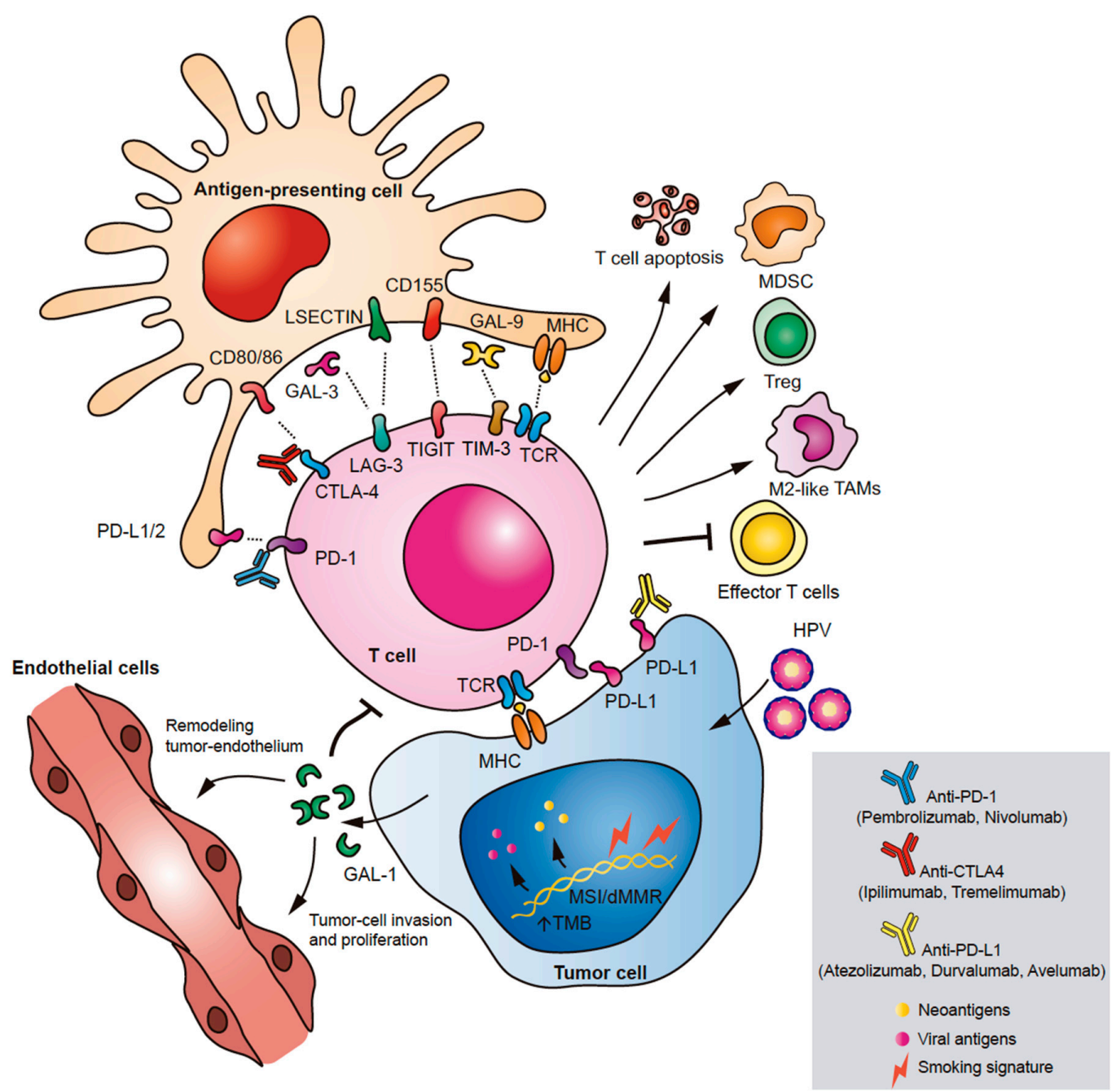

Figure 1. Immune checkpoints in head and neck squamous cell carcinoma (HNSCC). The main immune checkpoint pathways involved in HNSCC immune escape are illustrated: PD-1/PD-L1, CTLA-4, TIM-3, LAG-3, and TIGIT. Through different molecular mechanisms and signaling pathways, immune checkpoint molecules promote apoptosis of T cells, inhibit the effector function of T cells, and induce expansion of immunosuppressive MDSCs, M2-like TAMs, and Tregs. A novel soluble immune checkpoint implicated in HNSCC is Gal-1. Gal-1 is expressed by tumor cells triggering immune escape, modulation of tumor endothelium, and metastasis.

Research efforts are currently focused on understanding the mechanisms implicated in these alterations. Recent findings have shown that EZH2, a histone-lysine Nmethyltransferase enzyme, is inversely correlated with MHC-I expression in HNSCC. In vitro and in vivo blockade of EZH2 with small molecule inhibitors enhanced antigen presentation and antitumor immune responses. Based on these promising results, the combination of EZH2 inhibitor and anti-PD-1 mAb was proposed as an alternative therapeutic strategy to improve immunotherapy success in HNSCC [64].

\section{Immune Checkpoint Pathways Implicated in HNSCC}

Immune checkpoints are negative regulators of $\mathrm{T}$ cell activation while tuning the immune response to avoid its hyperactivation. The relevance of immune checkpoint pathways in tumor immune escape led to the design and implementation of several immunotherapeutic strategies to treat cancer. The major immune checkpoint pathways implicated in HNSCC immunosuppression are PD-1/PD-L1, cytotoxic T lymphocyte 
antigen 4 (CTLA-4), the T-cell immunoglobulin mucin 3 (TIM-3), the lymphocyte activation gene 3 (LAG-3), and T-cell immunoglobulin and immunoreceptor tyrosine-based inhibitory motif (TIGIT) (Figure 1).

\subsection{CTLA-4}

CTLA- 4 is a cell surface molecule mainly expressed on T cells, especially Tregs and exhausted Teff cells. CTLA-4 interacts with CD80 (B7-1), and CD86 (B7-2) expressed on the surface of APCs. CTLA-4 binding to CD80 or CD86 inhibits T cell activation by inhibiting signaling through the TCR. The primary cells affected by the activation of this immune checkpoint are activated T cells in lymph nodes (LN), dendritic cells (DCs), and exhausted Teff cells. This molecule acts mainly through the downmodulation of $\mathrm{CD} 4^{+} \mathrm{T}$ helper function while enhancing Tregs activity [65]. CTLA-4 was the first negative regulator of T cell activation identified in the context of antitumor immunity, and its blockade using mAbs triggers tumor regression and a durable antitumor immunity in preclinical models [66].

CTLA-4 expression is increased in HNSCC tumor samples compared to normal tissue and is not correlated with LN metastasis or pathological tumor grade [67]. Interestingly, Yu and colleagues observed that CD8/CTLA-4 ratio negatively correlates with prognosis and the frequency of MDSCs and M2 macrophages regardless of HPV infection [67]. Likewise, previous studies have shown that both tumor-infiltrating and circulating Tregs upregulate CTLA-4 in HNSCC patients [32,35], being higher the frequency of CTLA- $4^{+}$cells on intratumoral Tregs as well as their immunosuppressive activity [31] through several mechanisms involving TGF- $\beta 1$. Besides these observations in human samples, the blockade of CTLA-4 in an immune-competent mouse model of HNSCC significantly reduced MDSCs, M2 macrophages, and tumor burden while improving the effector function of $\mathrm{T}$ cells [67]. Similarly, the treatment with anti-CTLA- 4 mAb in a preclinical model of HNSCC that recapitulates the tobacco-related molecular profile showed complete response and no tumor recurrence accompanied by an increase of $\mathrm{CD} 8^{+} \mathrm{T}$-cell infiltration and a reduction in Tregs cell proportion [68]. Therefore, CTLA-4 expression by HNSCC tumors is an important immunosuppressive mechanism both in humans and mice and an attractive therapeutic target. In this regard, CTLA-4 blockade could improve clinical benefits of cetuximab based on the observation that CTLA $-4^{+}$Tregs increase with cetuximab treatment and via TGF- $\beta$-dependent mechanisms suppress cetuximab-mediated antibody-dependent cellular cytotoxicity, correlating with poor survival [69].

\section{2. $P D-1 / P D-L 1$}

PD-1 belongs to the CD28 family of co-stimulatory molecules expressed on the cell surface of tumor-infiltrating lymphocytes (TILs) such as Tregs, NK, T, and B cells. This coinhibitory molecule interacts with the glycoprotein ligands PD-L1 and PD-L2. Both APCs and tumor cells express high amounts of PD-L1, which contribute to T-cell inhibition. The primary mechanism by which PD-1/PD-L1 interaction blunts immune responses involves inhibition of TCR intracellular signaling in Teff and Tregs cells, influencing T-cell survival, proliferation, and cytotoxicity. Chronic exposure of $\mathrm{T}$ cells to tumor antigens can lead to the expression of high levels of PD-1 on their surface, favoring a T-cell exhaustion profile [65]. Recently, Gao and colleagues have shown that nuclear PD-L1 regulates gene expression of several immune-related genes through its binding to the DNA. Mechanistically, PDL1 translocates into the nucleus in an acetylation-dependent manner of the C-tail and binds directly to the DNA or interacts with specific transcription factors stimulating the expression of genes involved in inflammatory and antigen presentation pathways as well as enhancing the expression of other immune checkpoint inhibitors that could lead to acquired resistance to anti-PD-1/PD-L1 treatment [70]. Besides the relevant role of the PD-1/PDL1 axis in mediated immunosuppression in the TME, Dammeijer et al. showed that this pathway could also be activated in tumor-draining lymph node (TDLN), which are enriched in tumor-specific PD-1 T cells abolishing the current idea that only occurs at the tumor site. 
In particular, PD-1/PD-L1 association in TDLN impair systemic antitumor response, and in melanoma patients, its abundance is associated with disease recurrence [71].

PD-L1 is expressed in histologically aggressive and T-cell enriched HNSCC tumors [72]. Moreover, PD-L1 expression has been associated with EMT in HNSCC patients [73], and although around $60 \%$ of HNSCC tumors express PD-L1, it is more frequent in $\mathrm{HPV}^{+}$specimens [74]. Additionally, a higher infiltration of PD- $1^{+}$cells, mainly CD4 ${ }^{+}$and $\mathrm{CD}^{+} \mathrm{T}$ cells, in $\mathrm{HPV}^{+}$tumors correlates with better survival [75]. Tumor-infiltrating and peripheral Tregs of HNSCC patients express high levels of PD-1 on the cell surface, triggering immunosuppression [35]. Interestingly, circulating PD-L1 ${ }^{+}$-tumor-derived exosomes (TEX) are associated with disease progression (disease activity, tumor stage, and nodal involvement) in HNSCC patients. Moreover, PD-L1+-TEX can induce T cell dysfunction on activated $\mathrm{CD}^{+} \mathrm{T}$ cells in ex vivo assays and the in vitro blockade of these exosomes with an antiPD-1 mAbs enhances antitumor immune response by reversing this immunosuppressive effects on $\mathrm{CD}^{+} \mathrm{T}$ cells [76].

Regarding the molecular mechanisms associated with PD-L1 expression in HNSCC, a recent study showed that PD-L1 is induced by cell-intrinsic and -extrinsic pathways downstream of EGFR and IFN- $\gamma$, both dependent on JAK2/STAT1. Indeed, in vitro studies showed that JAK2 inhibition impaired IFN $\gamma$-mediated PD-L1 upregulation at mRNA and protein level in tumor cells [74].

\section{3. $L A G-3$}

LAG-3 is a transmembrane CD4-related protein expressed on B cells, DCs, NK, and activated T cells surface. Particularly, Tregs express high amounts of LAG-3, which amplifies their immunosuppressive activity by enhancing IL-10 production. Like PD-1, LAG-3 is upregulated in exhausted T cells. Ligands for LAG-3 include MHC-II, Galectin-3 (Gal-3), and liver sinusoidal endothelial cell lectin (LSECtin) expressed by certain tumor types [65]. Gal-3 is expressed by both tumor and immune cells, mostly M2 macrophages [77]. LAG-3 inhibits $\mathrm{CD}^{+}$and $\mathrm{CD}^{+} \mathrm{T}$ cell effector functions and proliferation. It is thought that LAG-3 functions in coordination with other checkpoint molecules to promote T-cell dysfunction. However, the molecular mechanisms and pathways implicated in LAG-3 signaling are still under scrutiny. In this regard, the conserved KIEELE motif of the cytoplasmatic domain was shown to be indispensable for LAG-3 downstream signaling and inhibition of CD4 ${ }^{+}$ $\mathrm{T}$ cells activation [78], and further studies demonstrated that MHC-II/LAG-3 triggers the activation of ITAM signaling in DCs, fostering a tolerogenic profile [79]. Therefore, MHC-II/LAG-3 interaction functions as a bidirectional inhibitory pathway. On the other hand, Gal-3/LAG-3 interactions modulate the innate branch of the antitumor immune response, mainly DCs and macrophages, and suppress CD8 ${ }^{+} \mathrm{T}$ cell effector functions [80].

The role of LAG-3 in HNSCC has been studied for a long time in both preclinical or in vitro models and human samples. In a genetic mouse model of HNSCC characterized by complete loss of Pten and Tgfb1r, LAG-3 expression is increased on CD4 ${ }^{+}$and CD8 ${ }^{+}$ $\mathrm{T}$ cells, as well as in Tregs. Furthermore, the in vivo administration of anti-LAG-3 mAb in this immunocompetent mouse model suppressed tumor growth and unleashed the antitumor $\mathrm{CD}^{+} \mathrm{T}$ cell-mediated response [81], supporting the relevant role of LAG-3 as an immune checkpoint and a possible therapeutic target in HNSCC. Likewise, LAG3 is overexpressed on TILs of HNSCC patients, and its expression correlates with high pathological grade, tumor size, and worse prognosis [81]. It also correlates with CD8 ${ }^{+}$ $\mathrm{T}$ cells and immunosuppressive cells, including Tregs, M2 macrophages, and MDSCs. A recent study using single-cell RNA sequencing (scRNA-Seq) from peripheral blood leukocytes of HNSCC patients showed that LAG-3 is expressed mainly on CD8 ${ }^{+} \mathrm{T}$ cells. A significant proportion of cancer patients express intracellular LAG-3 in peripheral CD8 ${ }^{+} \mathrm{T}$ cells, which correlates with the intracellular expression on matched TILs, poor prognosis, and decreased antitumor immune response [82]. 


\subsection{TIM-3}

TIM-3 is a negative co-stimulatory molecule expressed on $\mathrm{CD} 4^{+} \mathrm{Th} 1, \mathrm{CD} 8^{+} \mathrm{T}$ cells, Tregs, and other tumor cells. One of the TIM-3 ligands involved in immune regulation is Gal-9, which promotes apoptosis of Th1 cells, suppresses CD8 ${ }^{+} \mathrm{T}$ cell activity, and induces expansion of MDSCs [65].

In HNSCC, TIM-3 expression was observed in inflammatory cells, particularly CD8 ${ }^{+}$ $\mathrm{T}$ cells and MDSCs, and is upregulated compared to normal mucosa and dysplasia. Furthermore, the high expression of TIM-3 is associated with LN metastasis and recurrence but not with OS. Expression of the TIM-3 ligand Gal-9 is not restricted to tumor cells, but it is also expressed on immune cells in the tumor stroma of HNSCC tumors. In this context, TIM-3/Gal-9 expression is closely associated with the Tregs and M2-like macrophages [83]. To further understand the role of TIM-3 in HNSCC development and progression, Liu and colleagues observed that the in vivo inhibition of TIM-3 in a preclinical immunocompetent mouse model controlled tumor growth by restoring the immune response, particularly increases the frequency of Teff in tumor and LN through modulation of TIM-3 expression in these cells and reduces the recruitment of MDSCs into the TME in a CXCL1 dependentmanner [84]. TIM-3 blockade also reduces Treg frequency and enhances IFN- $\gamma$ production by $\mathrm{CD} 8^{+} \mathrm{T}$ cell [83].

Interestingly, in two orthotopic mouse models of HNSCC, the treatment with RT and anti-PD-1 mAb induced the upregulation of TIM- 3 in CD8 ${ }^{+}$and $\mathrm{CD} 4^{+} \mathrm{T}$ cells, mainly in Tregs, mediating treatment resistance. Although targeting TIM-3 in addition to PD-L1 and RT results in tumor growth delay and improved survival through reducing intratumoral Tregs frequency, the response is not durable since remaining infiltrating Tregs are highly proliferative and could expand, fostering tumor recurrence [34]. Thus, TIM-3 expression is a mechanism of tumor evasion in HNSCC, and its blockade is an attractive immunotherapeutic target.

\subsection{TIGIT}

TIGIT is a co-inhibitory receptor expressed in lymphocytes, particularly in effector and regulatory $\mathrm{CD}^{+} \mathrm{T}$ cells, and in tumor cells. By binding to CD155, expressed on the surface of APCs, TIGIT dampens $\mathrm{T}$ cell hyperactivation, proliferation, and differentiation [65]. TIGIT is overexpressed on either peripheral T cells and tumor-infiltrating CD8 ${ }^{+}$and $\mathrm{CD} 4^{+}$ T cells in HNSCC patients. Expression of the TIGIT ligand CD155 is higher in HNSCC than in normal tissue and is associated with worse OS and poor prognosis [85]. Thus, the blockade of this pathway may promote an active immunity against HNSCC tumors. Indeed, TIGIT inhibition significantly delayed tumor growth in HNSCC mouse models and enhanced antitumor immune responses by activating effector $\mathrm{CD}^{+} \mathrm{T}$ cells and reducing immunosuppressive cells, including Tregs and MDSCs [85]. High expression of TIGIT correlates with improved survival, only in $\mathrm{HPV}^{+}$tumors [86].

\section{Immune Checkpoint Blockade (ICB) in HNSCC Treatment}

The use of mAbs targeting immune checkpoint pathways gave rise to modern immunotherapeutic modalities that revolutionized the treatment of cancer patients, including those with HNSCC. In 2016, the results from the KEYNOTE-012 trial guaranteed the approval of anti-PD-1 agent Pembrolizumab by the FDA for patients with R/M HNSCC with disease progression on or after platinum-containing chemotherapy regardless of HPV status. KEYNOTE-012 was an open-label, multicenter, phase Ib clinical trial testing Pembrolizumab in R/M HNSCC patients proving that it was well tolerated while inducing a strong antitumoral activity with an overall response rate of $18 \%[87,88]$. These results were confirmed on the KEYNOTE-055 trial, which focused on R/M HNSCC after progression to platinum and cetuximab treatment [89]. Based on these results, two randomized phase III clinical trials evaluated the anti-PD-1 mAbs (Nivolumab or Pembrolizumab) in R/M HNSCC patients or HNSCC patients who progressed within six months to platinumbased chemotherapy, the CheckMate-141 and the KEYNOTE-040 trial, respectively. In 
the CheckMate-141 trial, Nivolumab was compared against the SoC systemic therapy (methotrexate, docetaxel, or cetuximab), showing longer OS on the Nivolumab arm with 7.5 months compared with 5.1 months with less toxicity [90], which allowed FDA to approve Nivolumab for R/M HNSCC patients. Likewise, the KEYNOTE-040 trial showed that Pembrolizumab-treated patients had increased OS compared to SoC, 8.4 months versus 6.9 months, respectively, and less treatment-related adverse events supporting its further testing as monotherapy or in combination in patients with early-stage disease. The median duration of response was 18.4 months in Pembrolizumab-treated patients compared with only 5.0 in the SoC arm, and the clinical benefit of Pembrolizumab (PFS and objective response rate (ORR)) relative to $\mathrm{SoC}$ was greater in those patients whose tumors express PD-L1 (Tumor proportion score (TPS) $\geq 50$; or CPS $\geq 1$ ) [91]. Later, in 2019, based on the KEYNOTE-048 results, Pembrolizumab was approved as monotherapy by the FDA as a first-line treatment for patients with PD-L1-positive R/M HNSCC or in combination with platinum and 5-fluorouracil in R/M HNSCC. In particular, KEYNOTE-048, a randomized, open-label phase III study, showed that Pembrolizumab alone or with chemotherapy improved median response duration by more than 16 and 2.5 months, respectively, versus cetuximab with chemotherapy. Moreover, Pembrolizumab monotherapy's profound OS benefits were observed only in patients with PD-L1-positive tumors (CPS $\geq 1$ ), while for Pembrolizumab with chemotherapy in all participants, regardless of the CPS score. Compared to standard therapy, the safety profile was favorable for Pembrolizumab alone or similar for Pembrolizumab with chemotherapy [92].

JAVELIN 100 is a randomized, double-blind, phase III clinical trial testing safety and antitumor efficacy of Avelumab, an anti-PD-L1 blocking monoclonal antibody, in combination with SoC chemoradiotherapy (SoC-CRT) against placebo plus SoC-CRT, as a first-line treatment in patients with locally advanced HNSCC being the primary endpoint PFS [93]. The study was completed recently, and the interim results presented in ESMO 2020 showed no significant improvement in PFS (based on 224 events) and OS (based on 131 events) with Avelumab plus SoC-CRT.

Besides the PD-1/PD-L1 axis, another checkpoint that has been widely explored as a therapeutic target is CTLA-4, with Ipilimumab and Tremelimumab being the two fully-humanized CTLA-4 antibodies most commonly used [94,95]. There is no anti-CTLA4-based immunotherapy approved for the treatment of HNSCC. However, several ongoing clinical trials evaluate the combinations of anti-CTLA- 4 antibodies with other immunotherapies or the current SoC HNSCC therapies. The hypothesis that the combination of therapies could yield better clinical benefits is being tested with good results in many cancer types. In this regard and based on previous observations of Durvalumab activity in R/M HNSCC, the EAGLE (NCT02369874) study is a phase III clinical trial testing the efficacy of Durvalumab, an anti-PD-L1 antibody alone or combined with Tremelimumab against SoC in patients with R/M HNSCC progressed after platinum-based therapy. The results recently published show no statistically significant differences in OS and PFS for Durvalumab or Durvalumab plus Tremelimumab versus SoC. Although ORR was similar among each arm, the only complete responses were observed in the immunotherapy ones. Furthermore, the median DoR was longer for Durvalumab and Durvalumab plus Tremelimumab compared to $\mathrm{SoC}$, being 12.9, 7.4, and 3.7 months, respectively. Durvalumab showed antitumor activity, and the combination with Tremelimumab is tolerable despite not improving patient survival [96]. The NCT04080804 clinical trial is currently recruiting patients before surgery with locally advanced HNSCC to test if Nivolumab's combination with Ipilimumab or Relatlimab (anti-LAG-3) potentiates antitumor immunity, thus enhancing the response to Nivolumab. Another therapeutic approach to block the LAG-3 immune checkpoint is by targeting its ligand Gal-3. In this regard, the NCT02575404 phase I clinical trial is currently testing the combination of Pembrolizumab with a specific Gal-3 inhibitor, GR-MD-02, in solid tumors, including HNSCC. 
Several ongoing clinical trials are testing either the combination of different ICB or ICB with other therapies like chemoradiotherapy and vaccines. This is shortly discussed in the next section and summarized in Table 1.

\subsection{Combination of ICB with Other Therapies}

Given the success of immunotherapy, several clinical trials are designed to test whether the efficacy of SoC CRT can be enhanced with the addition of different ICB. DURTRE-RAD trial (NCT03624231) is a two-arms, randomized, multicenter phase II study recruiting patients with non-resectable locally advanced HPV ${ }^{-} \mathrm{HNSCC}$ to test Durvalumab or Durvalumab and Tremelimumab in combination with radiotherapy as first-line treatment. As the combination of anti-PD-L1 and anti-CTLA-4 plus radiotherapy resulted in high toxicity, the trial is currently ongoing only for anti-PD-L1 alone or in combination with radiotherapy [97].

Based on the results of the KEYNOTE-040 and KEYNOTE-048, the KEYNOTE-412 (NCT03040999), a phase III clinical trial with 780 patients with locally advanced HNSCC, is taking place. Patients will be split in two groups; an experimental arm will be treated with a combination of Pembrolizumab, cisplatin, and radiotherapy; and the placebo arm will be treated with the same combination of cisplatin and radiotherapy, but with a placebo instead of Pembrolizumab. The primary hypothesis is that Pembrolizumab given in combination with SoC CRT is superior in event-free survival (disease progression or death in a maximum time frame of five years) than the SoC CRT. The investigators plan to complete the study by 2023 and believe that this trial may elucidate Pembrolizumab's role when added to SoC in patients for whom five-year survival rates are poor, besides gaining insight on factors that influence the efficacy of immunotherapy by studying biomarkers data [98].

Besides the clinical trials previously discussed, there are others that are currently evaluating the combination of anti-PD-1 immunotherapies with targeted therapies such as Cetuximab (NCT03082534), Lenvatinib (a multikinase inhibitor of VEGFR 1-3, FGFR 1-4, PDGFRa, RET, and KIT; NCT02501096), Itacitinib (PI3K-delta inhibitor, NCT02646748), among others. Moreover, a clinical trial evaluating Acalabrutinib, a BTK inhibitor, has just been completed (NCT02454179).

\subsection{Combination of ICB with Other Immunotherapies}

Several clinical trials are testing the combination of PD-1/PD-L1 immune checkpoint inhibition with vaccination. The use of cancer vaccines as treatment is based on providing antigens to activate the immune system, promote an antitumor immune response, or overcome immunosuppression. The NCT02426892 phase II clinical trial is testing the combination of ISA101, a synthetic long-peptide HPV-16 vaccine inducing HPV-specific T cells, with Nivolumab. The study aims to determine whether this combination amplifies

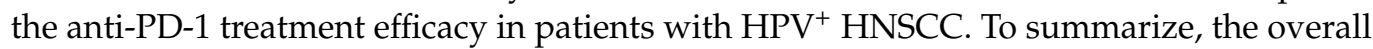
response rate observed was $33 \%$ and a median OS of 17.5 months; these were promising results when compared to PD-1 monotherapy. However, the antitumor effects of the vaccine are yet to be studied [99]. Another clinical trial evaluating the safety and efficacy of an HPV-vaccine is the NCT03260023. Specifically, the study tests the combination of Avelumab with TG4001 in patients with R/M HPV-16-positive cancer. Preliminary results showed that the combination is safe and provides antitumor immunity. There is a shift in gene expression signatures towards a more active innate and adaptive immune response [100].

The use of oncolytic viruses is an immunotherapy strategy that utilizes a virus to replicate in tumor cells resulting in their lysis, leading to an immunogenic cell death and subsequent activation of the antitumor immune response. In this regard, there is an ongoing clinical trial, the MASTERKEY232/KEYNOTE-137 (NCT0262600), which aims to evaluate the safety and efficacy of Pembrolizumab in combination with TVEC, a genetically modified type I herpes simplex virus, in R/M HNSCC. The first results demonstrated the safety and clinical activity for the combination under study. 


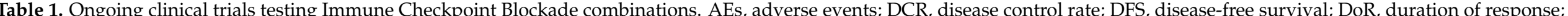

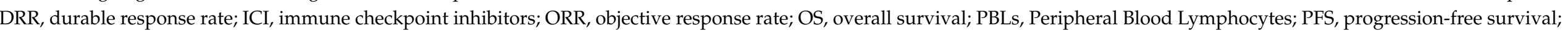

QOL, quality of life; SAEs, serious adverse events; SoC, standard of care; TIL, Tumor Infiltrating Lymphocyte.

\begin{tabular}{|c|c|c|c|c|c|c|}
\hline $\begin{array}{l}\text { Clinical Trial NCT } \\
\text { Number }\end{array}$ & Clinical Trial Title & Status & Interventions & $\begin{array}{l}\text { Immune } \\
\text { Checkpoint Tested }\end{array}$ & Clinical Trial Details & $\begin{array}{c}\text { Enrollment (Number } \\
\text { of Patients) }\end{array}$ \\
\hline NCT04454489 & $\begin{array}{l}\text { Quad Shot Radiotherapy } \\
\text { in Combination } \\
\text { with Immune Checkpoint } \\
\text { Inhibition }\end{array}$ & $\begin{array}{l}\text { Not yet } \\
\text { recruiting }\end{array}$ & $\begin{array}{l}\text { - Quad-shot palliative radiotherapy + } \\
\text { Pembrolizumab }\end{array}$ & PD-1 & $\begin{array}{l}\text { Phase: } \\
\text { - Phase II } \\
\text { Intervention Model Description: } \\
\text { - Single group assignment, non-randomized } \\
\text { Outcome Measures: } \\
\text { - ORR } \\
\text { Response rate in the target lesions and in the } \\
\text { non-target lesions } \\
\text { DoR at the target lesions } \\
\text { - Percentage of participants with PFS and OS } \\
\text { Incidences of AEs }\end{array}$ & 15 \\
\hline NCT03313804 & $\begin{array}{l}\text { Priming Immunotherapy } \\
\text { in Advanced } \\
\text { Disease with Radiation }\end{array}$ & Recruiting & $\begin{array}{l}\text { Nivolumab+ Radiation (Stereotactic Body } \\
\text { Radiation Therapy OR fractionated radiation } \\
\text { therapy) } \\
\text { Pembrolizumab+ Radiation (Stereotactic Body } \\
\text { Radiation Therapy OR fractionated radiation } \\
\text { therapy) } \\
\text { Atezolizumab + Radiation (Stereotactic Body } \\
\text { Radiation Therapy OR fractionated radiation } \\
\text { therapy) }\end{array}$ & $\begin{array}{l}\text { PD-1/ } \\
\text { PD-L1 }\end{array}$ & 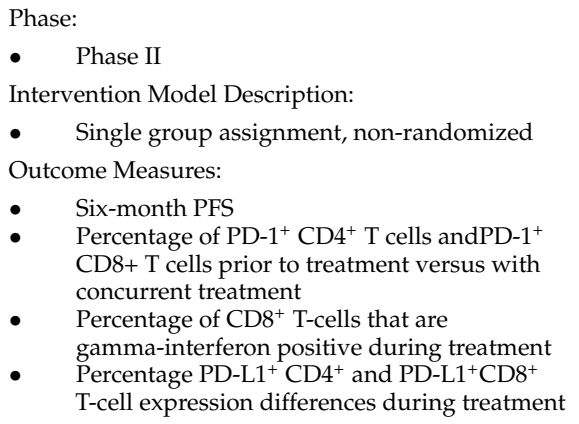 & 57 \\
\hline NCT03228667 & $\begin{array}{l}\text { QUILT-3.055: A Study of } \\
\text { Combination } \\
\text { Immunotherapies in } \\
\text { Patients Who Have } \\
\text { Previously Received } \\
\text { Treatment with } \\
\text { Immune Checkpoint } \\
\text { Inhibitors }\end{array}$ & Recruiting & $\begin{array}{l}\text { Cohort 1: Patients who progressed on or after a } \\
\text { single-agent ICI after experiencing an initial CR or PR. } \\
\text { N-803 + Pembrolizumab or Nivolumab or Atezolizumab } \\
\text { or Avelumab or DurvalumabCohort } 2 \text { and Cohort } 3 \text { only } \\
\text { for selected NSCLC patients. } \\
\text { Experimental Cohort } 4 \text { : Patients who are currently } \\
\text { receiving PD-1/PD-L1 checkpoint inhibitor therapy and } \\
\text { have disease progression after experiencing SD for at } \\
\text { least } 6 \text { months during their previous treatment with } \\
\text { PD-1/PD-L1 checkpoint inhibitor therapy } \\
\text { N-803 + Pembrolizumab or Nivolumab or Atezolizumab } \\
\text { or Avelumab or Durvalumab } \\
\text { Experimental Cohort 5: Patients who experienced disease } \\
\text { progression by Investigator-assessment per irRECIST } \\
\text { while receiving treatment in Cohorts 1-4 N-803 + } \\
\text { Pembrolizumab or Nivolumab or Atezolizumab or } \\
\text { Avelumab or Durvalumab + PD-L1 t-haNK }\end{array}$ & $\begin{array}{l}\text { PD-1/ } \\
\text { PD-L1 }\end{array}$ & $\begin{array}{l}\text { Phase: } \\
\text { - Phase II } \\
\text { Intervention Model Description: } \\
\text { - Parallel assignment, non-randomized } \\
\text { Outcome Measures: } \\
\text { : ORR } \\
\text { D OS } \\
\text { OSe-specific survival } \\
\text { Time to Response } \\
\text { DoR } \\
\text { - } \quad \text { QOL } \\
\quad \text { PFS }\end{array}$ & 636 \\
\hline
\end{tabular}


Table 1. Cont.

\begin{tabular}{|c|c|c|c|c|c|c|}
\hline $\begin{array}{l}\text { Clinical Trial NCT } \\
\text { Number }\end{array}$ & Clinical Trial Title & Status & Interventions & $\begin{array}{c}\text { Immune } \\
\text { Checkpoint Tested }\end{array}$ & Clinical Trial Details & $\begin{array}{l}\text { Enrollment (Number } \\
\text { of Patients) }\end{array}$ \\
\hline NCT03522584 & $\begin{array}{c}\text { Durvalumab, } \\
\text { Tremelimumab and } \\
\text { Hypofractionated } \\
\text { Radiation Therapy } \\
\text { in Treating Patients with } \\
\text { Recurrent or } \\
\text { Metastatic Head and Neck } \\
\text { Squamous Cell } \\
\text { Carcinoma }\end{array}$ & Recruiting & $\begin{array}{l}\text { Durvalumab + Tremelimumab + Radiation (Hypo } \\
\text { fractionated radiation therapy using either HIGRT } \\
\text { or SBRT) }\end{array}$ & $\begin{array}{l}\text { PD-L1 } \\
\text { CTLA-4 }\end{array}$ & $\begin{array}{l}\text { Phase: } \\
\text { - Phase I } \\
\text { Intervention Model Description: } \\
\text { - } \quad \text { Single group assignment } \\
\text { Outcome Measures: } \\
\text { : } \quad \text { Incidence of AEs } \\
\text { ORR } \\
\text { PFS } \\
\quad \text { OS }\end{array}$ & 20 \\
\hline NCT03544723 & $\begin{array}{l}\text { Safety and Efficacy of p53 } \\
\text { Gene Therapy } \\
\text { Combined with Immune } \\
\text { Checkpoint } \\
\text { Inhibitors in Solid Tumors. }\end{array}$ & Recruiting & $\begin{array}{l}\text { - Ad-p53 with anti-PD-1/anti-PD-L1 (based on FDA } \\
\text { approved) }\end{array}$ & PD-1 & $\begin{array}{l}\text { Phase: } \\
\text { - Phase II } \\
\text { Intervention Model Description } \\
\text { - Parallel assignment, non-randomized } \\
\text { Outcome Measures: } \\
\text { - } \quad \text { ORR } \\
\text { - } \quad \text { Preety assessments of AES } \\
\text { - Preliminary assessment of DoR by RECIST } 1.1 \\
\text { PFS by RECIST } 1.1\end{array}$ & 40 \\
\hline
\end{tabular}


Table 1. Cont.

\begin{tabular}{|c|c|c|c|c|c|c|}
\hline $\begin{array}{c}\text { Clinical Trial NCT } \\
\text { Number }\end{array}$ & Clinical Trial Title & Status & Interventions & $\begin{array}{c}\text { Immune } \\
\text { Checkpoint Tested }\end{array}$ & Clinical Trial Details & $\begin{array}{c}\text { Enrollment (Number } \\
\text { of Patients) }\end{array}$ \\
\hline NCT03944915 & $\begin{array}{c}\text { De-Escalation Therapy for } \\
\text { Human } \\
\text { Papillomavirus Negative } \\
\text { Disease }\end{array}$ & Recruiting & $\begin{array}{ll}\text { - } & \text { Carboplatin }+ \text { Paclitaxel }+ \text { Nivolumab (Induction } \\
\text { - } & \text { Therapy) } \\
\text { Radiation therapy with Chemotherapy }\end{array}$ & PD-1 & $\begin{array}{l}\text { Phase: } \\
\text { - Phase II } \\
\text { Intervention Model: } \\
\text { - Single group assignment, non-randomized } \\
\text { Outcome Measured: } \\
\text { : } \quad \text { DRR } \\
\text { PFS } \\
\text { OS } \\
\quad \text { cocoregional and distant control after } \\
\quad \text { completing chemoradiation }\end{array}$ & 36 \\
\hline NCT03426657 & $\begin{array}{l}\text { Radiotherapy with Double } \\
\text { Checkpoint } \\
\text { Blockade of Locally } \\
\text { Advanced HNSCC }\end{array}$ & Recruiting & Durvalumab + Tremelimumab + Radiation therapy & $\begin{array}{c}\text { PD-L1 } \\
\text { CTLA-4 }\end{array}$ & $\begin{array}{l}\text { Phase: } \\
\text { - Phase II } \\
\text { Intervention Model: } \\
\text { - Prospective, open-label, non-randomized } \\
\text { Outcome Measured: } \\
\text { - Number of participants receiving the protocol } \\
\text { treatment until cycle } 6 \text { of antibody treatment } \\
\text { Predictive character of changes of CD } 8^{+} \text {tumor } \\
\text { infiltrating immune cells after induction } \\
\text { chemoimmunotherapy } \\
\text { - Absence of any dose-limiting toxicities } \\
\text { PFS }\end{array}$ & 120 \\
\hline NCT03841110 & $\begin{array}{l}\text { FT500 as Monotherapy } \\
\text { and in Combination } \\
\text { with Immune Checkpoint } \\
\text { Inhibitors in } \\
\text { Subjects with Advanced } \\
\text { Solid Tumors }\end{array}$ & Recruiting & $\begin{array}{ll}- & \text { FT500 Monotherapy } \\
\text { FT500 in Combination with Nivolumab, } & \text { Pembrolizumab or Atezolizumab }\end{array}$ & $\begin{array}{l}\text { PD-1/ } \\
\text { PD-L1 }\end{array}$ & $\begin{array}{l}\text { Phase: } \\
\text { - Phase I } \\
\text { Intervention Model: } \\
\text { - Parallel assignment, non-randomized } \\
\text { Outcome Measured: } \\
\text { - The incidence of subjects with dose-limiting } \\
\quad \text { toxicities within each dose level cohort to } \\
\text { determine the Maximum Tolerated Dose } \\
\text { ORR } \\
\text { - Duration of FT500 persistence }\end{array}$ & 76 \\
\hline
\end{tabular}


Table 1. Cont.

\begin{tabular}{|c|c|c|c|c|c|c|}
\hline $\begin{array}{c}\text { Clinical Trial NCT } \\
\text { Number }\end{array}$ & Clinical Trial Title & Status & Interventions & $\begin{array}{c}\text { Immune } \\
\text { Checkpoint Tested }\end{array}$ & Clinical Trial Details & $\begin{array}{c}\text { Enrollment (Number } \\
\text { of Patients) }\end{array}$ \\
\hline NCT03377400 & $\begin{array}{l}\text { Definitive CCRT } \\
\text { Combined with } \\
\text { Durvalumab and } \\
\text { Tremelimumab for } \\
\text { Inoperable Esophageal } \\
\text { Cancer }\end{array}$ & $\begin{array}{l}\text { Active, not } \\
\text { Recruiting }\end{array}$ & - $\quad 5 \mathrm{FU} / \mathrm{CDDP}+$ Durvalumab/Tremelimumab & $\begin{array}{l}\text { PD-L1 } \\
\text { CTLA-4 }\end{array}$ & $\begin{array}{l}\text { Phase: } \\
\text { - Phase II } \\
\text { Intervention Model: } \\
\text { - Single group assignment. } \\
\text { Outcome Measured: } \\
\text { - PFS }\end{array}$ & 40 \\
\hline NCT03673735 & $\begin{array}{l}\text { Maintenance Immune } \\
\text { Check-point Inhibitor } \\
\text { Following Post-Operative } \\
\text { Chemo-radiation in } \\
\text { Subjects with } \\
\text { HPV-negative HNSCC }\end{array}$ & $\begin{array}{c}\text { Not yet } \\
\text { recruiting }\end{array}$ & $\begin{array}{l}\text { - } \quad \text { Durvalumab before Chemoradiotherapy and for } 6 \\
\text { months every } 4 \text { weeks after CRT } \\
\text { - Control: placebo before CRT and for } 6 \text { months } \\
\text { every } 4 \text { weeks after CRT Radiotherapy }\end{array}$ & PD-L1 & $\begin{array}{l}\text { Phase: } \\
\text { - Phase III } \\
\text { Intervention Model: } \\
\text { - Parallel assignment, randomized } \\
\text { Outcome Measured: } \\
\text { - } \quad \text { OFS } \\
\text { OS } \\
\quad \text { locoregianalive incidence of distant metastases, } \\
\text { (all sites) } \\
\text { - } \quad \text { QOL of toxicity assessed by clinicians }\end{array}$ & 650 \\
\hline NCT04393506 & $\begin{array}{l}\text { Inductive Camrelizumab } \\
\text { and Apatinib } \\
\text { for Patients with Locally } \\
\text { Advanced and } \\
\text { Resectable Oral Squamous } \\
\text { Cell Carcinoma }\end{array}$ & Recruiting & $\begin{array}{l}\text { - Camrelizumab and Apatinib, followed by radical } \\
\text { surgery and post-operative } \\
\text { radiotherapy/chemoradiotherapy }\end{array}$ & PD-1 & $\begin{array}{l}\text { Phase: } \\
\text { - Phase I } \\
\text { Intervention Model: } \\
\text { - Sequential assignment. } \\
\text { Outcome Measured: } \\
\text { - Major pathologic response } \\
\text { - Two-year OS } \\
\quad \text { Two-year tumor recurrence rate }\end{array}$ & 20 \\
\hline NCT03946358 & $\begin{array}{l}\text { Combination of UCPVax } \\
\text { Vaccine and } \\
\text { Atezolizumab for the } \\
\text { Treatment of Human } \\
\text { Papillomavirus Positive } \\
\text { Cancers (VolATIL) }\end{array}$ & Recruiting & - $\quad$ Atezolizumab + UCPVax & PD-L1 & $\begin{array}{l}\text { Phase: } \\
\bullet \quad \text { Phase II } \\
\text { Intervention Model: } \\
\text { - Single group assignment } \\
\text { Outcome Measures: } \\
\text { O ORR at } 4 \text { months } \\
\text { OS } \\
\text { PFS } \\
\quad \text { Health-related quality of life (HrQoL) }\end{array}$ & 47 \\
\hline
\end{tabular}


Table 1. Cont.

\begin{tabular}{|c|c|c|c|c|c|c|}
\hline $\begin{array}{c}\text { Clinical Trial NCT } \\
\text { Number }\end{array}$ & Clinical Trial Title & Status & Interventions & $\begin{array}{c}\text { Immune } \\
\text { Checkpoint Tested }\end{array}$ & Clinical Trial Details & $\begin{array}{l}\text { Enrollment (Number } \\
\quad \text { of Patients) }\end{array}$ \\
\hline NCT04058145 & $\begin{array}{l}\text { AMD3100 Plus } \\
\text { Pembrolizumab in } \\
\text { Immune Checkpoint } \\
\text { Blockade Refractory Head } \\
\text { and Neck Squamous Cell } \\
\text { Carcinoma }\end{array}$ & Recruiting & $\begin{array}{ll}\text { - } & \text { Pembrolizumab + AMD3100 Q3w } \\
\text { - } & \text { Pembrolizumab + AMD3100 weekly } \\
& \end{array}$ & PD-1 & $\begin{array}{l}\text { Phase: } \\
\text { - Phase II } \\
\text { Intervention Model: } \\
\text { - Parallel assignment, randomized. } \\
\text { Outcome Measures: } \\
\text { - } \quad \text { Participants that experience a dose limiting } \\
\text { toxicity } \\
\text { ORR } \\
\text { PFS } \\
\text { OS } \\
\text { - } \quad \text { Darticipants with AEs } \\
\quad \text { Duration of response }\end{array}$ & 57 \\
\hline NCT04080804 & $\begin{array}{l}\text { Study of Safety and } \\
\text { Tolerability of Nivolumab } \\
\text { Treatment Alone or in } \\
\text { Combination with } \\
\text { Relatlimab or Ipilimumab } \\
\text { in Head and Neck Cancer }\end{array}$ & Recruiting & $\begin{array}{ll}- & \text { Nivolumab + Relatlimab } \\
\text { - } & \text { Nivolumab + Ipilimumab } \\
& \text { Nivolumab }\end{array}$ & $\begin{array}{l}\text { PD-1 } \\
\text { CTLA-4 } \\
\text { LAG-3 }\end{array}$ & $\begin{array}{l}\text { Phase: } \\
\text { - Phase II } \\
\text { Intervention Model: } \\
\text { - Parallel assignment, randomized. } \\
\text { Outcome Measures: } \\
\text { - } \quad \text { AEs related to monotherapy or combinations } \\
\text { - } \quad \text { Leviographic of TIL subsense } \\
\text { - } \quad \text { Levels of PBLs } \\
\text { - TMB } \\
\quad \text { Gene expression signature }\end{array}$ & 60 \\
\hline NCT03690986 & $\begin{array}{l}\text { VX15/2503 in } \\
\text { Combination with } \\
\text { Ipilimumab or Nivolumab } \\
\text { in Patients with Head and } \\
\text { Neck Cancer }\end{array}$ & Recruiting & $\begin{array}{ll} & \text { Group A: VX15/2503 } \\
\text { - } & \text { Group B: VX15/2503 + Ipilimumab) } \\
\text { - } & \text { Group C: VX15/2503 + Nivolumab) } \\
\text { - } & \text { Group E: Iivolumamab } \\
& \text { Group Fo no treatment }\end{array}$ & $\begin{array}{c}\text { PD-1 } \\
\text { CTLA-4 }\end{array}$ & $\begin{array}{l}\text { Phase: } \\
\text { - Phase I } \\
\text { Intervention Model: } \\
\text { - Parallel assignment, randomized } \\
\text { Outcome Measures: } \\
\text { - Change in immune profile in the TME } \\
\text { - Change in circulating percentage of immune } \\
\text { - Puppressor subsets in peripheral blood } \\
\text { - } \quad \text { periphericher bhifts in T-lymphocyte subsets in } \\
\text { Incidence of AEs }\end{array}$ & 36 \\
\hline
\end{tabular}


Table 1. Cont.

\begin{tabular}{|c|c|c|c|c|c|c|}
\hline $\begin{array}{c}\text { Clinical Trial NCT } \\
\text { Number }\end{array}$ & Clinical Trial Title & Status & Interventions & $\begin{array}{c}\text { Immune } \\
\text { Checkpoint Tested }\end{array}$ & Clinical Trial Details & $\begin{array}{c}\text { Enrollment (Number } \\
\text { of Patients) }\end{array}$ \\
\hline NCT02718820 & $\begin{array}{l}\text { Pembrolizumab Plus } \\
\text { Docetaxel for the } \\
\text { Treatment of Recurrent or } \\
\text { Metastatic Head and Neck } \\
\text { Cancer }\end{array}$ & $\begin{array}{l}\text { Active, not } \\
\text { recruiting }\end{array}$ & - $\quad$ Docetaxel + Pembrolizumab & PD-1 & $\begin{array}{l}\text { Phase: } \\
\text { - Phase I } \\
\text { Intervention Model: } \\
\text { - } \quad \text { Single group assignment } \\
\text { Outcome Measures: } \\
\text { : Overall response rate } \\
\text { : } \quad \text { Individuall response rate } \\
\text { QoL } \\
\text { OS } \\
\text { - } \quad \text { AFS } \\
\quad \text { AEs }\end{array}$ & 22 \\
\hline NCT03684785 & $\begin{array}{c}\text { Intratumoral } \\
\text { Cavrotolimod Combined } \\
\text { with Pembrolizumab or } \\
\text { Cemiplimab in Patients } \\
\text { with Advanced Solid } \\
\text { Tumors }\end{array}$ & Recruiting & $\begin{array}{l}\text { - Dose escalation phase 1b: AST-008 + } \\
\text { Pembrolizumab } \\
\text { Dose expansion phase 2, Meker cell carcinoma, } \\
\text { patients that have progressed on an } \\
\text { anti-PD-1/PD-L1 therapy or are otherwise } \\
\text { refractory to CPI therapy: AST-008 + } \\
\text { Pembrolizumab } \\
\text { Dose expansion phase 2, cutaneous squamous cell } \\
\text { carcinoma, patients that have progressed on an } \\
\text { anti-PD-1/PD-L1 therapy or are otherwise } \\
\text { refractory to CPI therapy: AST-008 + Cemiplimab }\end{array}$ & PD-1 & $\begin{array}{l}\text { Phase: } \\
\text { - Phase Ib } \\
\text { Intervention Model: } \\
\text { - Sequential Assignment, randomized } \\
\text { Outcome Measures: } \\
\text { - AEs } \\
\text { Disease assessment wit RECIST } 1.1 \\
\text { - Safety evaluation of AST-008 alone or in } \\
\text { combination } \\
\text { PFS and OS } \\
\text { - Pharmacokinetic parameters } \\
\text { Disease control rate }\end{array}$ & 130 \\
\hline NCT03212469 & $\begin{array}{c}\text { A Trial of Durvalumab and } \\
\text { Tremelimumab in } \\
\text { Combination with SBRT in } \\
\text { Patients with Metastatic } \\
\text { Cancer (ABBIMUNE) }\end{array}$ & Recruiting & - $\quad$ Durvalumab + Tremelimumab + SBRT radiation & $\begin{array}{c}\text { PD-1 } \\
\text { CTLA-4 }\end{array}$ & $\begin{array}{l}\text { Phase: } \\
\text { - } \quad \text { Phase I } \\
\text { Intervention Model: } \\
\text { - Parallel assignment, non-randomized } \\
\text { Outcome Measures: } \\
\text { - } \quad \text { Dose-limiting toxicity }\end{array}$ & 55 \\
\hline
\end{tabular}


Table 1. Cont.

\begin{tabular}{|c|c|c|c|c|c|c|}
\hline $\begin{array}{l}\text { Clinical Trial NCT } \\
\text { Number }\end{array}$ & Clinical Trial Title & Status & Interventions & $\begin{array}{c}\text { Immune } \\
\text { Checkpoint Tested }\end{array}$ & Clinical Trial Details & $\begin{array}{l}\text { Enrollment (Number } \\
\text { of Patients) }\end{array}$ \\
\hline NCT03818061 & $\begin{array}{l}\text { Atezolizumab and } \\
\text { Bevacizumab in Patients } \\
\text { with Recurrent or } \\
\text { Metastatic Squamous-Cell } \\
\text { Carcinoma of the Head } \\
\text { and Neck (ATHENA) }\end{array}$ & Recruiting & - $\quad$ Atezolizumab + Bevacizumab in $\mathrm{HPV}^{+}$or $\mathrm{HPV}^{-}$ & PD-L1 & $\begin{array}{l}\text { Phase: } \\
\text { - Phase II } \\
\text { Intervention Model: } \\
\text { - Parallel assignment, non-randomized } \\
\text { Outcome Measures: } \\
\text { - ORR } \\
\text { - Disease control rate } \\
\text { - Dest OR } \\
\text { PFS } \\
\text { - OS } \\
\quad \text { Others: immune cell characterization, } \\
\quad \text { microbiome analysis, immuno-phenotyping }\end{array}$ & 110 \\
\hline NCT03829501 & $\begin{array}{l}\text { Safety and Efficacy of } \\
\text { KY1044 and Atezolizumab } \\
\text { in Advanced Cancer }\end{array}$ & Recruiting & $\begin{array}{ll}\text { - } & \text { KY1044 monotherapy phase } 1 \text { (dose escalation) } \\
\text { KY1044 + Atezolizumab phase } 1 \text { (dose escalation) } \\
\text { KY1044 monotherapy phase } 2 \\
\text { KY1044 + Atezolizumab phase } 2\end{array}$ & $\begin{array}{l}\text { PD-L1 } \\
\text { ICOS }\end{array}$ & $\begin{array}{l}\text { Phase: } \\
\text { - Phase I } \\
\text { Intervention Model: } \\
\text { - Sequential assignment, non-randomized } \\
\text { Outcome Measures: } \\
\text { - } \quad \text { AEs and SAEs } \\
\text { Number of dose interruptions, reductions and } \\
\text { Oose intensity } \\
\text { ORR } \\
\text { Survival rate } \\
\text { DoR } \\
\text { OS } \\
\text { Others: immune cell characterization, } \\
\text { microbiome analysis, immuno-phenotyping }\end{array}$ & 412 \\
\hline
\end{tabular}


Table 1. Cont.

\begin{tabular}{|c|c|c|c|c|c|c|}
\hline $\begin{array}{c}\text { Clinical Trial NCT } \\
\text { Number }\end{array}$ & Clinical Trial Title & Status & Interventions & $\begin{array}{c}\text { Immune } \\
\text { Checkpoint Tested }\end{array}$ & Clinical Trial Details & $\begin{array}{l}\text { Enrollment (Number } \\
\text { of Patients) }\end{array}$ \\
\hline NCT02551159 & $\begin{array}{l}\text { Phase III Open Label } \\
\text { Study of MEDI } 4736 \\
\text { with/without } \\
\text { Tremelimumab Versus } \\
\text { Standard of Care (SoC) in } \\
\text { Recurrent/Metastatic } \\
\text { Head and Neck Cancer }\end{array}$ & $\begin{array}{l}\text { Active, not } \\
\text { recruiting }\end{array}$ & $\begin{array}{ll}- & \text { MEDI4736 monotherapy } \\
& \text { MEDI4736+Tremelimumab } \\
& \text { SoC }\end{array}$ & $\begin{array}{l}\text { PD-L1 } \\
\text { CTLA-4 }\end{array}$ & $\begin{array}{l}\text { Phase: } \\
\text { - Phase III } \\
\text { Intervention Model: } \\
\text { - Parallel assignment, randomized } \\
\text { Outcome Measures: } \\
\text { - Efficacy of MEDI4736 monotherapy compared } \\
\text { - to SoC in terms of OS } \\
\text { The efficacy of MEDI } 4736 \text { + Tremelimumab } \\
\text { combination therapy compared to SoC in } \\
\text { terms of OS, ORR, PFS, Second Progression } \\
\text { (PFS2) and DoR } \\
\text { The efficacy of MEDI4736 + Tremelimumab } \\
\text { combination therapy compared to SoC in } \\
\text { terms of best objective response (BoR), Time to } \\
\text { First Subsequent Therapy (TFST), and Time to } \\
\text { Second Subsequent Therapy (TSST) } \\
\text { Others: immune cell characterization, } \\
\text { microbiome analysis, immuno-phenotyping }\end{array}$ & 823 \\
\hline NCT03517488 & $\begin{array}{l}\text { A Study of XmAb®20717 } \\
\text { in Subjects with Selected } \\
\text { Advanced Solid Tumors } \\
\text { (DUET-2) }\end{array}$ & Recruiting & - $\quad$ XmAb20717 (bispecific antibody) & $\begin{array}{c}\text { PD-1 } \\
\text { CTLA-4 }\end{array}$ & $\begin{array}{l}\text { Phase: } \\
\text { - Phase I } \\
\text { Intervention Model: } \\
\text { - Sequential assignment, randomized } \\
\text { Outcome Measures: } \\
\text { - Determine the safety and tolerability profile of } \\
\quad \text { XmAb20717 }\end{array}$ & 154 \\
\hline NCT03693612 & $\begin{array}{l}\text { GSK3359609 Plus } \\
\text { Tremelimumab for the } \\
\text { Treatment of Advanced } \\
\text { Solid Tumors }\end{array}$ & Recruiting & $\begin{array}{l}\text { - GSK3359609+ Tremelimumab (subjects with R/R } \\
\text { HNSCC who have disease progression after } \\
\text { receiving at least one platinum-based } \\
\text { chemotherapy and at least one anti-PD-1/PD-L1) } \\
\text { SoC treatment }\end{array}$ & $\begin{array}{l}\text { ICOS } \\
\text { CTLA-4 }\end{array}$ & $\begin{array}{l}\text { Phase: } \\
\text { - Phase II } \\
\text { Intervention Model: } \\
\text { - Parallel assignment, randomized } \\
\text { Outcome Measures: } \\
\text { - Number of subjects with dose-limiting } \\
\text { - } \quad \text { Ovicities } \\
\text { Diseall response rate } \\
\text { - } \quad \text { PFS } \\
\text { DoR } \\
\quad \text { Others }\end{array}$ & 114 \\
\hline
\end{tabular}


Table 1. Cont.

\begin{tabular}{|c|c|c|c|c|c|c|}
\hline $\begin{array}{c}\text { Clinical Trial NCT } \\
\text { Number }\end{array}$ & Clinical Trial Title & Status & Interventions & $\begin{array}{c}\text { Immune } \\
\text { Checkpoint Tested }\end{array}$ & Clinical Trial Details & $\begin{array}{c}\text { Enrollment (Number } \\
\text { of Patients) }\end{array}$ \\
\hline NCT02575404 & $\begin{array}{l}\text { GR-MD-02 Plus } \\
\text { Pembrolizumab in } \\
\text { Melanoma, Non-Small } \\
\text { Cell Lung Cancer, and } \\
\text { Squamous Cell Head and } \\
\text { Neck Cancer Patients }\end{array}$ & Recruiting & $\begin{array}{l}\text { GR-MD-02 in combination with standard } \\
\text { Pembrolizumab treatment }\end{array}$ & $\begin{array}{c}\text { Gal-3 } \\
\text { /LAG3 axis } \\
\text { PD-1 }\end{array}$ & $\begin{array}{l}\text { Phase: } \\
\text { - Phase Ib } \\
\text { Intervention Model: } \\
\text { - Parallel assignment, non-randomized } \\
\text { Outcome Measures: } \\
\text { - Frequency and severity of treatment-related } \\
\text { adverse events measured by Common } \\
\text { Terminology Criteria for Adverse Events } \\
\text { (CTCAEs) Version } 4.0 \text { overall response rate } \\
\text { Measure the response rate to combined } \\
\text { therapy with GR-MD-02 and Pembrolizumab } \\
\text { in patients } \\
\text { Assess the biological activity of GR-MD-02 in } \\
\text { combination with Pembrolizumab }\end{array}$ & 22 \\
\hline
\end{tabular}




\subsection{ICB in the Neoadjuvant Setting}

Around $50 \%$ of patients with locally advanced HNSCC develop recurrence and / or distant metastasis after definitive local therapy. Although there have been many attempts to improve survival with induction or neoadjuvant chemotherapy, none have demonstrated efficacy. Due to the effectiveness of ICB in R/M disease, most of the ongoing clinical trials testing neoadjuvant settings have immunotherapy as a foundation of the study (reviewed by Reference [101]).

NCT02296684 was one of the first clinical trials testing Pembrolizumab as neoadjuvant or adjuvant therapy in high-risk patients with locally advanced HNSCC treated with the current SoC surgical approaches. The results showed that Pembrolizumab was safe and there was low locoregional recurrences or distant metastasis at the time of the one-year follow-up [102]. Likewise, preliminary results of the phase I/II Checkmate-358 trial suggest that patients can benefit from Nivolumab in the neoadjuvant setting regardless of their HPV status [103]. Furthermore, the NCT02641093 phase II trial testing Pembrolizumab with cisplatin and radiation as adjuvant therapy in resected HNSCC shows promising results and suggests that pathological response is accompanied by robust immune cell infiltration at surgery time [104]. Besides these trials focused on PD-1 inhibitors, others are blocking PD-L1. In this regard, IMvoke010 (NCT03452137), an ongoing phase III clinical trial, aims to evaluate the efficacy in terms of PFS and the safety of Atezolizumab as adjuvant therapy in patients with high-risk locally advanced HNSCC [105].

Based on the synergism of the dual blockade of PD-1 and CTLA-4, many clinical trials are testing this combination. For instance, the phase III clinical trial IMSTAR-HN (NCT03700905) is currently recruiting patients with locally advanced HNSCC for the treatment with Nivolumab in combination with Ipilimumab in the adjuvant/neoadjuvant setting [106].

In addition to these studies, there are numerous other ongoing clinical trials. In summary, neoadjuvant immunotherapy has shown an acceptable safety profile, being well-tolerated in HNSCC patients with promising efficacy. However, many questions remain to be answered, such as adequate dosing and duration of treatment.

\section{Biomarkers of Response to Immunotherapy in HNSCC}

Nivolumab and Pembrolizumab have been approved for treating patients with R/M disease, most HNSCC patients' progress to therapy. Therefore, there is an urgent need to develop and validate robust predictive biomarkers, to improve the selection of patients who will receive clinical benefit [107]. Indeed, integrating biomarkers of response to immunotherapy is proposed to correctly select the best treatment options for each patient [108]. In the following sections, we discuss biomarkers that have been evaluated in HNSCC.

\subsection{Tumor Genomic Features: Microsatellite Instability and Tumor Mutational Burden}

Microsatellite Instability (MSI) is an underlying genetic process contributing to high Tumor Mutation Burden (TMB) and consequent neo-antigen formation. TMB and MSI are indirect measures of tumor antigenicity generated by somatic mutations. Therefore, they are both predictive biomarkers of response to immunotherapy treatment in several malignancies.

Tumors with high MSI show improved response to checkpoint inhibition, an effect which was first demonstrated in patients with metastatic colorectal carcinoma treated with anti-PD-1 therapy [109]. Accumulating evidence suggests that both genomics of MSIpositive tumors and their respective microenvironment enriched in CD8 T cells contribute to high response rates to immunotherapy [110]. In 2017, the FDA approved Nivolumab and Pembrolizumab to treat MSI-positive cancers of any histology [111]. Despite the low frequency of MSI in HNSCC tumors, the Society of Immunotherapy of Cancer (SITC) recommends its testing to predict response to PD-L1 inhibitors [107]. Several studies and meta-analyses propose the TMB as a promising biomarker in HNSCC and other 
solid malignancies like non-small-cell lung cancer (NSCLC) and melanoma, where there is a positive correlation between OS and response rates to immunotherapy [112,113]. Despite these observations, the SITC has not currently recommended TMB analyses for HNSCC [107]. However, the FDA approved in June 2020 the use of Pembrolizumab for the treatment of previously treated solid tumors including anal, biliary, cervical, endometrial, mesothelioma, neuroendocrine, salivary, small-cell lung, thyroid, and vulvar cancers patients with high TMB (TMB-H) [ $\geq 10$ Mutations/Megabase (Mut/Mb)].

\subsection{Tobacco Smoke and HPV Status}

Tobacco smoking is one of the major risk factors for the development and progression of HNSCC and is an important prognostic factor for survival and mortality after diagnosis [6]. Tobacco smoking generates DNA damage, induces mutations, and modifies the tumor immune microenvironment. Particularly, HNSCC tumors that harbor a genetic smoking signature have a lower immune infiltrate, local immunosuppression, and diminished IFN- $\gamma$ signaling and cytolytic activity $[22,114,115]$. Furthermore, a smoking signature correlates with poor OS and high TMB load in HNSCC tumors [22,115]. Even though the smoking signature is positively associated with response to ICB in NSCLC [116], there is little evidence in the literature correlating smoking status and response to immunotherapy in HNSCC. Interestingly, for two cohorts of HNSCC patients treated with anti-PD-1/PD-L1 inhibitors, never-smokers have higher clinical benefit than current/former smokers $[90,115]$.

Besides tobacco smoking, HPV infection is another significant risk factor for the development of HNSCC. Indeed, the HPV infection is related to around $20-25 \%$ of all HNSCC cases, and they are clinically and biologically distinct from their non-viral counterparts [117]. $\mathrm{HPV}^{+} \mathrm{HNSCC}$ tumors, particularly OSCC, are associated with good prognosis [7]. Interestingly, smoker status is associated with worse OS in $\mathrm{HPV}^{+}$tumors. This may be explained by the genetic alterations induced by tobacco-associated carcinogens rendering $\mathrm{HPV}^{+}$tumors less responsive to therapy [7]. The HPV infection in HNSCC promotes an inflamed immune microenvironment with higher CD8 T cell activation, Tregs, and greater levels of CTLA-4 expression [22]. However, there is no robust evidence supporting differential clinical benefit despite the effects of HPV status in the TME. Therefore, the SITC does not recommend using the HPV status to stratify HNSCC patients [107].

\subsection{PD-L1 Expression}

PD-L1 expression on the tumor and immune cells has been associated with improved treatment outcomes to anti-PD-1/PD-L1 immunotherapy. Indeed, it has been approved by the FDA as a predictive biomarker of response in several cancers such as NSCLC, bladder, and cervical cancer, among others [118]. Specifically, in HNSCC, PD-L1 expression by IHC on tumor and infiltrating immune cells has been widely studied as a biomarker of response to PD-1/PD-L1 ICB. Furthermore, current evidence supports that the CPS offers a higher predictive value than the TPS [107]. In this regard, patients enrolled in the KEYNOTE-012 showed no differences in ORR between PD-L1 ${ }^{+}$and PD-L1' patients when using a TPS $\geq 1$. However, with CPS, PD-L1 ${ }^{+}$patients had increased ORR. The relevance of CPS as a biomarker was also demonstrated in the KEYNOTE-048 where patients with CPS $\geq 20$ and CPS $\geq 1$ benefit from Pembrolizumab monotherapy while for Pembrolizumab plus chemotherapy was independent of the PD-L1 status. Likewise, the KEYNOTE-040 demonstrated that patients treated with Pembrolizumab with a CPS $\geq 1$ have an improved OS. However, some patients negative for PD-L1 expression still benefit from therapy, suggesting that the predictive value of PD-L1 expression is not absolute. In this regard, a challenge to use PD-L1 as a biomarker in HNSCC is the intra- and inter-tumor heterogeneity [107]. Rasmussen and colleagues observed in 16 HNSCC patients that PD-L1 expression varies within the tumor, affecting both the TPS and CPS [119]. Similarly, in NSCLC, PD-L1 expression has been recently associated with the anatomical site of the biopsy, and its predictive value is also different for each site [120]. On the other hand, a recent comparative study among three different PD-L1 IHC assays showed moderate 
concordance among the assays and considerable differences in PD-L1 positivity [121]. The recent findings suggest that TEXs carrying functional PD-L1 can induce immunosuppression inhibiting Teff cells [122]. In this regard, Theodoraki and colleagues observed that high levels of TEX- PD-L1 ${ }^{+}$at baseline and its reduction during treatment are associated with response in HNSCC patients [123]. Thus, they have been recently proposed as potential non-invasive biomarkers to monitor patients' response to treatment [122,123].

\subsection{T-Cell Inflamed Gene Expression and Novel Insights into the TME}

A T-cell inflamed gene expression signature has been significantly associated with overall response and PFS to anti-PD-1 therapy in HNSCC and in other solid tumors like melanoma. The T-cell inflamed signature comprises IFN- $\gamma$-responsive genes related to antigen presentation, chemokine expression, cytotoxic activity, and adaptive immune resistance. Thus, this T-cell inflamed profile could be a useful biomarker based on its high predictive value [124]

Apart from T cells, other tumor-infiltrating immune cells like macrophages, myeloid cells, and NK cells are also relevant in modulating the TME improving tumor responses to treatment [25]. The use of bioinformatic tools to infer the composition of the immune infiltrate from transcriptomic data of tumor biopsies is becoming more relevant and useful. Moreover, scRNA-seq studies are critical to further understand the underlying molecular mechanisms of response and resistance to treatment at a cellular level. By applying bioinformatic methods on tumor biopsies sequencing data, researchers hope to improve biomarkers' precision to stratify patients better and propose novel therapeutic targets. A recent study by Chen and colleagues shows a novel immune molecular classification of HNSCC with implications on immunotherapy response. Based on immune-related gene signatures representing immune status or immune cells, the authors [125] described two subgroups on The Cancer Genome Atlas (TCGA) HNSCC cohort and other six independent cohorts. While the Active Immune class was enriched in B-cell and M1 macrophages infiltration and cytolytic activity (markers of immune activation), the Exhausted Immune class was enriched in activated-stroma, M2 macrophages infiltration, and TGF- $\beta 1$ expression (markers of immune exhaustion). When these classes were studied on a melanoma cohort of patients treated with anti-PD-1, the Active Immune class was associated with patients that responded to therapy showing its good predictive value [125].

The development of single-cell genomics methods in the last years has provided new ways to explore the TME. Specifically, scRNA-Seq experiments reveal the inter- and intra-tumoral heterogeneity in cancer cells and their association with different stromal and immune cells in the TME [126]. In a scRNA-Seq study of primary tumors and LN metastasis biopsies from HNSCC patients, Puram and colleagues [127] found consistent immune cell populations and expression profiles across patients, while they differ their proportions in the TME. In the T cell compartment, they found four sub-populations (Tregs, conventional $\mathrm{CD}^{+} \mathrm{T}$ helper cells, and two cytotoxic $\mathrm{CD} 8^{+} \mathrm{T}$ cells) differing in the expression of co-inhibitory molecules. Interestingly, the gene expression profiles of cytotoxic $\mathrm{CD}^{+} \mathrm{T}$ cells revealed an exhaustion program characterized by the expression of different markers of T cell dysfunction and exhaustion such as LAG-3, TIGIT, PD-1, and CTLA-4. Notably, the proportion of $\mathrm{CD}^{+} \mathrm{T}$ cells varied between patients. This suggests a potential association with response to ICB and biomarkers in HNSCC. Furthermore, the study of malignant cells revealed that they clustered accordingly to their tumor of origin and presented differential expression of common signatures within each tumor, reflecting inter- and intra-tumoral heterogeneity [127].

Additional scRNA-Seq studies in tumor biopsies are necessary to reveal associations between the TME heterogeneity and resistance to treatment in HSNCC. The study of the immune cell compartment and its crosstalk with tumor cells and the TME is crucial to establish new biomarkers of response to immunotherapy and understanding the mechanisms underlying resistance at a cellular level. 


\subsection{Microbiota as a Potential Novel Biomarker of Response to Immunotherapy}

The oral microbiome is affected by common HNSCC risk factors, including HPV infection and tobacco smoking [128]. A retrospective study associated the oral abundance of certain bacteria with reduced HNSCC development risk [129]. For several cancer malignancies, the composition of the microbiota has been associated with immune dysregulation, cancer progression, and response to treatment $[130,131]$. Indeed, several shreds of evidence support the role of the gut microbiome in regulating the antitumor immune response and the success of immunotherapy in melanoma and hepatocellular carcinoma, among others $[132,133]$. The role of the microbiota in HNSCC and response to immunotherapy remains to be thoroughly studied. Only the CHECKMATE-141 clinical trial explored the oral microbiota composition in patients treated with Nivolumab, but no significant correlation with response to treatment or survival was observed.

\subsection{Novel Insights in Biomarkers: Combined and Integrative Strategies}

The current understanding of the clinical response to ICB suggests that any single biomarker cannot effectively identify patients due to the complexity of the tumor biology and immune response. Therefore, combining predictive biomarkers holds promise to be more effective and specific as a strategy to infer, identify and capture the immune status of tumors [108]. Cristescu et al. showed for different cancer types, including HNSCC, that TMB, PD-L1 expression, and T-cell inflamed gene expression profiles measure different aspects of the tumor immune response, as they are independent markers to predict the efficacy of anti-PD-1/PD-L1 therapy [113]. This suggests that every single biomarker provides complementary information of the TME, and its use in an integrated way will improve the identification of patients who will respond to immunotherapy. Indeed, ongoing efforts are currently focused on developing multifactorial predictive models by integrating data relative to different features of both tumor biology and tumor immune response. For instance, Wang and colleagues have recently developed a method to measure the tumor immunogenicity score (TIGS) that refers to the tumor antigenicity and its ability to present antigens to the immune cells. Particularly, the TIGS score combines TMB as a measure of tumor antigenicity and an antigen processing/presentation gene expression signature. Interestingly, the TIGS score has a better performance than TMB alone to predict response to ICB and correlates with ORR; and is also better than other biomarkers based only on gene expression profile (i.e., T-cell inflamed gene expression) [134]. Likewise, the immunophenoscore is a machine learning algorithm that generates an aggregated score from the expression of MHC molecules, immunomodulators, effectors, and suppressor cells with usefulness to predict survival and response [135]. Another successful strategy is multiplex IHC (mIHC) and multiplex immunofluorescence (mIF) for the study of the TME. In contrast to previously described biomarkers, $\mathrm{mIF} / \mathrm{mIHC}$ allows the visualization of several markers in the same tumor section, thus providing spatial and co-expression information. A recent systemic review and meta-analysis involving more than 10 cancer types, including HNSCC, has shown that both $\mathrm{mIHC} / \mathrm{mIF}$ had higher diagnostic accuracy in predicting clinical response to anti-PD-1/PD-L1 immunotherapy than PD-L1, TMB, or different gene expression signatures alone. Interestingly, its predictive value is similar to that reached by the combination of PD-L1 IHC, TMB, and/or gene expression [136].

In summary, the multidimensional examination of the TME by different approaches enhances the characterization and understanding of tumor heterogeneity thus enhancing the value in predicting immunotherapy treatment response. However, further studies and clinical trials are needed to confirm their biomarker potential.

\section{Conclusions and Future Directions}

HNSCC is one of the most highly immune-infiltrated cancer types. However, its immune microenvironment has immunosuppressive features and HNSCC tumors can successfully escape the antitumor immune response. Among the several mechanisms implicated in immune evasion, the expression of different immune checkpoint pathways 
has been of great interest due to the development of novel immunotherapeutic strategies targeting these pathways, which revolutionized the treatment of solid tumors, including HNSCC.

The only ICB approach approved to treat HNSCC involves inhibition of the immune checkpoint pathway PD-1/PD-L1 by the administration of mAbs against PD-1. Numerous ongoing clinical trials are interrogating the potential clinical benefit of its combination with other types of immune modulators or with other agents. Importantly, there are still many unresolved challenges to improve patient outcomes and the number of patients who will benefit from these therapies. Consequently, there is an urgent need for predictive biomarkers of response and prognosis. In this regard, PD-L1 expression, T-cell inflamed profile, and the TMB have been proposed as promising predictive biomarkers for HNSCC, while other candidate biomarkers not discussed in this review, such as circulating tumor cells and circulating tumor DNA, are under investigation. Furthermore, ongoing efforts are focused on biomarker integration strategies to enhance the predictive power by considering several tumor features at the same time. A novel and promising immunotherapeutic approach use autologous chimeric antigen receptor (CAR) $\mathrm{T}$ cells. Indeed, there is an ongoing phase I clinical trial for patients with locally advanced or recurrent disease (NCT01818323) testing the efficacy of the intra-tumoral administration of genetically engineered T-cells to express the following: T1E28z, second-generation of CAR containing a promiscuous ligand of ErbB; and $4 \alpha \beta$, a chimeric IL-4 receptor. By this approach, researchers aim to block ErbB receptors, which are known key players in the initiation of several solid tumors, including HNSCC, and favor the ex vivo T-cell expansion by IL-4 [137]. Both in vitro and preclinical studies revealed the antitumor activity of these T-cells. Many investigations are still underway, to identify and validate tumor-associated antigens and how to overcome the challenges associated with CAR T cells in treating solid tumors [138]. In this regard, Mei and colleagues have recently proposed mucin-1 (MUC-1) as a target for CAR-T cells based on the higher expression of this protein by tumor cells, compared to non-neoplastic tissue and the effective cytotoxicity of MUC-1 CAR-T cells in vitro and in vivo [139].

Due to the high heterogeneity of this cancer type, it is difficult to expand one therapeutic option to all patients. Basic, translational, and clinical research will be required to improve the treatment and management of HNSCC patients.

Funding: This research was funded by the Agencia Nacional de Promoción Científica y Tecnológica (PICT 2014-3687 and 2017-0494 to G.A. Rabinovich, and 2016-2130 to M.R. Girotti), Grupo Español de Melanoma GEM (to M.R. Girotti), Instituto Nacional del Cancer (to M.R. Girotti) and the Fundación Sales, and Fundación Bunge \& Born and Richard Lounsbery Foundation (to G.A. Rabinovich). The authors also thank the Baron Foundation for kind support.

Acknowledgments: The authors thank Marta Toscano for figure design.

Conflicts of Interest: The authors declare no conflict of interest.

\section{References}

1. Laura, Q.M.; Chow, M.D. Head and Neck Cancer. N. Engl. J. Med. 2020, 382, 60-72. [CrossRef]

2. Bray, F.; Ferlay, J.; Soerjomataram, I.; Siegel, R.L.; Torre, L.A.; Jemal, A. Global cancer statistics 2018: GLOBOCAN estimates of incidence and mortality worldwide for 36 cancers in 185 countries. CA Cancer J. Clin. 2018, 68, 394-424. [CrossRef]

3. WHO. Globocan 2018 Database. Issued by World Health Organization (WHO). Available online: http://gco.iarc.fr/today (accessed on 30 January 2021).

4. Mork, J.; Lie, A.K.; Glattre, E.; Clark, S.; Hallmans, G.; Jellum, E.; Koskela, P.; Møller, B.; Pukkala, E.; Schiller, J.T.; et al. Human Papillomavirus Infection as a Risk Factor for Squamous-Cell Carcinoma of the Head and Neck. J. Natl. Cancer Inst. 2001, 344, 1125-1131. [CrossRef]

5. Hashibe, M.; Brennan, P.; Benhamou, S.; Castellsagué, X.; Chen, C.; Curado, M.P.; Dal Maso, L.; Daudt, A.W.; Fabianova, E.; Franceschi, V.W.-F.S.; et al. Alcohol Drinking in Never Users of Tobacco, Cigarette Smoking in Never Drinkers, and the Risk of Head and Neck Cancer: Pooled Analysis in the International Head and Neck Cancer Epidemiology Consortium. J. N. Inst. 2007, 99, 777-789. [CrossRef]

6. Leemans, C.R.; Braakhuis, B.J.M.; Brakenhoff, R.H. The molecular biology of head and neck cancer. Nat. Rev. Cancer 2010, 11, 9-22. [CrossRef] 
7. $\quad$ Ang, K.K.; Harris, J.; Wheeler, R.; Weber, R.; Rosenthal, D.I.; Nguyen-Tân, P.F.; Westra, W.H.; Chung, C.H.; Jordan, R.C.; Lu, C.; et al. Human Papillomavirus and Survival of Patients with Oropharyngeal Cancer. N. Engl. J. Med. 2010, 363, 24-35. [CrossRef] [PubMed]

8. Leemans, C.R.; Snijders, P.J.F.; Brakenhoff, R.H. The molecular landscape of head and neck cancer. Nat. Rev. Cancer 2018, 18, 269-282. [CrossRef] [PubMed]

9. Machiels, J.-P.; Leemans, C.R.; Golusinski, W.; Grau, C.; Licitra, L.; Gregoire, V. Squamous cell carcinoma of the oral cavity, larynx, oropharynx and hypopharynx: EHNS-ESMO-ESTRO Clinical Practice Guidelines for diagnosis, treatment and follow-up. Ann. Oncol. 2020, 31, 1462-1475. [CrossRef] [PubMed]

10. Pai, S.I.; Westra, W.H. Molecular Pathology of Head and Neck Cancer: Implications for Diagnosis, Prognosis, and Treatment. Annu. Rev. Pathol. Mech. Dis. 2009, 4, 49-70. [CrossRef] [PubMed]

11. Fakhry, C.; Lacchetti, C.; Rooper, L.M.; Jordan, R.C.; Rischin, D.; Sturgis, E.M.; Bell, D.; Lingen, M.W.; Harichand-Herdt, S.; Thibo, J.; et al. Human Papillomavirus Testing in Head and Neck Carcinomas: ASCO Clinical Practice Guideline Endorsement of the College of American Pathologists Guideline. J. Clin. Oncol. 2018, 36, 3152-3161. [CrossRef]

12. Hashim, D.; Boffetta, P. Head and Neck Cancers. Occup. Cancers 2020, 57-105. [CrossRef]

13. Le, X.; Ferrarotto, R.; Wise-Draper, T.; Gillison, M. Evolving Role of Immunotherapy in Recurrent Metastatic Head and Neck Cancer. J. Natl. Compr. Cancer Netw. 2020, 18, 899-906. [CrossRef] [PubMed]

14. Sacco, A.G.; Cohen, E.E. Current Treatment Options for Recurrent or Metastatic Head and Neck Squamous Cell Carcinoma. J. Clin. Oncol. 2015, 33, 3305-3313. [CrossRef] [PubMed]

15. Subbiah, V.; Solit, D.; Chan, T.; Kurzrock, R. The FDA approval of pembrolizumab for adult and pediatric patients with tumor mutational burden $(\mathrm{TMB}) \geq 10$ : A decision centered on empowering patients and their physicians. Ann. Oncol. 2020, 31, 1115-1118. [CrossRef] [PubMed]

16. Gavrielatou, N.; Doumas, S.; Economopoulou, P.; Foukas, P.G.; Psyrri, A. Biomarkers for immunotherapy response in head and neck cancer. Cancer Treat. Rev. 2020, 84, 101977. [CrossRef] [PubMed]

17. Economopoulou, P.; De Bree, R.; Kotsantis, I.; Psyrri, A. Diagnostic Tumor Markers in Head and Neck Squamous Cell Carcinoma (HNSCC) in the Clinical Setting. Front. Oncol. 2019, 9, 827. [CrossRef] [PubMed]

18. Mehanna, H.; Rischin, D.; Wong, S.J.; Gregoire, V.; Ferris, R.; Waldron, J.; Le, Q.-T.; Forster, M.; Gillison, M.; Laskar, S.; et al. De-Escalation After De-Escalate and RTOG 1016: A Head and Neck Cancer InterGroup Framework for Future De-Escalation Studies. J. Clin. Oncol. 2020, 38, 2552-2557. [CrossRef]

19. Poeta, M.L.; Manola, J.; Goldwasser, M.A.; Forastiere, A.; Benoit, N.; Califano, J.A.; Ridge, J.A.; Goodwin, J.; Kenady, D.; Saunders, J.; et al. TP53Mutations and Survival in Squamous-Cell Carcinoma of the Head and Neck. N. Engl. J. Med. 2007, 357, $2552-2561$. [CrossRef]

20. Kern, S.E. Why Your New Cancer Biomarker May Never Work: Recurrent Patterns and Remarkable Diversity in Biomarker Failures. Cancer Res. 2012, 72, 6097-6101. [CrossRef]

21. Hunt, J.L. Applications of molecular testing in surgical pathology of the head and neck. Mod. Pathol. 2017, 30, S104-S111. [CrossRef]

22. Mandal, R.; Şenbabaoğlu, Y.; Desrichard, A.; Havel, J.J.; Dalin, M.G.; Riaz, N.; Lee, K.-W.; Ganly, I.; Hakimi, A.A.; Chan, T.A.; et al. The head and neck cancer immune landscape and its immunotherapeutic implications. JCI Insight 2016, 1, e89829. [CrossRef] [PubMed]

23. Ferris, R.L. Immunology and Immunotherapy of Head and Neck Cancer. J. Clin. Oncol. 2015, 33, 3293-3304. [CrossRef] [PubMed]

24. Hanahan, D.; Weinberg, R.A. Hallmarks of Cancer: The Next Generation. Cell 2011, 144, 646-674. [CrossRef]

25. Bruni, D.; Angell, H.K.; Galon, J. The immune contexture and Immunoscore in cancer prognosis and therapeutic efficacy. Nat. Rev. Cancer 2020, 20, 662-680. [CrossRef] [PubMed]

26. Reichert, T.E.; Rabinowich, H.; Johnson, J.T.; Whiteside, T.L. Mechanisms Responsible for Signaling and Functional Defects. J. Immunother. 1998, 21, 295-306. [CrossRef]

27. Reichert, T.E.; Strauss, L.; Wagner, E.M.; Gooding, W.; Whiteside, T.L. Signaling abnormalities, apoptosis, and reduced proliferation of circulating and tumor-infiltrating lymphocytes in patients with oral carcinoma. Clin. Cancer Res. 2002, 8, 3137-3145. [PubMed]

28. Upreti, D.; Zhang, M.-L.; Bykova, E.; Kung, S.K.P.; Pathak, K.A. Change in CD3ל-chain expression is an independent predictor of disease status in head and neck cancer patients. Int. J. Cancer 2016, 139, 122-129. [CrossRef] [PubMed]

29. Sakakura, K.; Chikamatsu, K.; Takahashi, K.; Whiteside, T.L.; Furuya, N. Maturation of circulating dendritic cells and imbalance of T-cell subsets in patients with squamous cell carcinoma of the head and neck. Cancer Immunol. Immunother. 2005, 55, 151-159. [CrossRef]

30. Hoffmann, T.K.; Dworacki, G.; Tsukihiro, T.; Meidenbauer, N.; Gooding, W.; Johnson, J.T.; Whiteside, T.L. Spontaneous apoptosis of circulating T lymphocytes in patients with head and neck cancer and its clinical importance. Clin. Cancer Res. 2002, 8, 2553. [PubMed]

31. De Ruiter, E.J.; Ooft, M.L.; Devriese, L.A.; Willems, S.M. The prognostic role of tumor infiltrating T-lymphocytes in squamous cell carcinoma of the head and neck: A systematic review and meta-analysis. OncoImmunology 2017, 6, e1356148. [CrossRef] [PubMed] 
32. Strauss, L.; Bergmann, C.; Szczepanski, M.J.; Gooding, W.E.; Johnson, J.T.; Whiteside, T.L. A Unique Subset of CD4+CD25highFoxp3+ $\mathrm{T}$ Cells Secreting Interleukin-10 and Transforming Growth Factor- $\beta 1$ Mediates Suppression in the Tumor Microenvironment. Clin. Cancer Res. 2007, 13, 4345-4354. [CrossRef]

33. Bergmann, C.; Strauss, L.; Wang, Y.; Szczepanski, M.J.; Lang, S.; Johnson, J.T.; Whiteside, T.L. T Regulatory Type 1 Cells in Squamous Cell Carcinoma of the Head and Neck: Mechanisms of Suppression and Expansion in Advanced Disease. Clin. Cancer Res. 2008, 14, 3706-3715. [CrossRef]

34. Oweida, A.; Hararah, M.K.; Phan, A.V.; Binder, D.C.; Bhatia, S.; Lennon, S.; Bukkapatnam, S.; Van Court, B.; Uyanga, N.; Darragh, L.; et al. Resistance to Radiotherapy and PD-L1 Blockade Is Mediated by TIM-3 Upregulation and Regulatory T-Cell Infiltration. Clin. Cancer Res. 2018, 24, 5368-5380. [CrossRef] [PubMed]

35. Jie, H.-B.; Gildenerleapman, N.; Li, J.; Srivastava, R.M.; Gibson, S.P.; Whiteside, T.L.; Ferris, R.L. Intratumoral regulatory T cells upregulate immunosuppressive molecules in head and neck cancer patients. Br. J. Cancer 2013, 109, 2629-2635. [CrossRef] [PubMed]

36. Seminerio, I.; Descamps, G.; Dupont, S.; De Marrez, L.; Laigle, J.-A.; Lechien, J.R.; Kindt, N.; Journe, F.; Saussez, S. Infiltration of FoxP3+ Regulatory T Cells is a Strong and Independent Prognostic Factor in Head and Neck Squamous Cell Carcinoma. Cancers 2019, 11, 227. [CrossRef] [PubMed]

37. Badoual, C.; Hans, S.; Rodriguez, J.; Peyrard, S.; Klein, C.; Agueznay, N.E.H.; Mosseri, V.; Laccourreye, O.; Bruneval, P.; Fridman, W.H.; et al. Prognostic Value of Tumor-Infiltrating CD4+ T-Cell Subpopulations in Head and Neck Cancers. Clin. Cancer Res. 2006, 12, 465-472. [CrossRef]

38. Shang, B.; Liu, Y.; Jiang, S.-J.; Liu, Y. Prognostic value of tumor-infiltrating FoxP3+ regulatory T cells in cancers: A systematic review and meta-analysis. Sci. Rep. 2015, 5, 15179. [CrossRef] [PubMed]

39. Lang, S.; Bruderek, K.; Kaspar, C.; Höing, B.; Kanaan, O.; Dominas, N.; Hussain, T.; Droege, F.; Eyth, C.; Hadaschik, B.; et al. Clinical Relevance and Suppressive Capacity of Human Myeloid-Derived Suppressor Cell Subsets. Clin. Cancer Res. 2018, 24, 4834-4844. [CrossRef]

40. Greene, S.; Robbins, Y.; Mydlarz, W.K.; Huynh, A.P.; Schmitt, N.C.; Friedman, J.; Horn, L.A.; Palena, C.; Schlom, J.; Maeda, D.Y.; et al. Inhibition of MDSC Trafficking with SX-682, a CXCR1/2 Inhibitor, Enhances NK-Cell Immunotherapy in Head and Neck Cancer Models. Clin. Cancer Res. 2020, 26, 1420-1431. [CrossRef] [PubMed]

41. Mantovani, A.; Sica, A.; Sozzani, S.; Allavena, P.; Vecchi, A.; Locati, M. The chemokine system in diverse forms of macrophage activation and polarization. Trends Immunol. 2004, 25, 677-686. [CrossRef]

42. She, L.; Qin, Y.; Wang, J.; Liu, C.; Zhu, G.; Li, G.; Wei, M.; Chen, C.; Liu, G.; Zhang, D.; et al. Tumor-associated macrophages derived CCL18 promotes metastasis in squamous cell carcinoma of the head and neck. Cancer Cell Int. 2018, 18, 120. [CrossRef] [PubMed]

43. Troiano, G.; Caponio, V.C.A.; Adipietro, I.; Tepedino, M.; Santoro, R.; Laino, L.; Russo, L.L.; Cirillo, N.; Muzio, L.L. Prognostic significance of CD68+ and CD163+ tumor associated macrophages in head and neck squamous cell carcinoma: A systematic review and meta-analysis. Oral Oncol. 2019, 93, 66-75. [CrossRef] [PubMed]

44. Kumar, A.T.; Knops, A.; Swendseid, B.; Martinez-Outschoom, U.; Harshyne, L.; Philp, N.; Rodeck, U.; Luginbuhl, A.; Cognetti, D.; Johnson, J.; et al. Prognostic Significance of Tumor-Associated Macrophage Content in Head and Neck Squamous Cell Carcinoma: A Meta-Analysis. Front. Oncol. 2019, 9, 656. [CrossRef] [PubMed]

45. Bu, L.-L.; Yu, G.-T.; Deng, W.-W.; Mao, L.; Liu, J.-F.; Ma, S.-R.; Fan, T.-F.; Hall, B.; Kulkarni, A.B.; Zhang, W.-F.; et al. Targeting STAT3 signaling reduces immunosuppressive myeloid cells in head and neck squamous cell carcinoma. OncoImmunology 2016, 5, e1130206. [CrossRef]

46. Lathers, D. Increased aberrance of cytokine expression in plasma of patients with more advanced squamous cell carcinoma of the head and neck. Cytokine 2004, 25, 220-228. [CrossRef]

47. Allen, C.T.; A Duffy, S.; Teknos, T.N.; Islam, M.; Chen, Z.; Albert, P.S.; Wolf, G.T.; Van Waes, C. Nuclear Factor-kB-Related Serum Factors as Longitudinal Biomarkers of Response and Survival in Advanced Oropharyngeal Carcinoma. Clin. Cancer Res. 2007, 13, 3182-3190. [CrossRef] [PubMed]

48. De Medeiros, M.C.; Banerjee, R.; Liu, M.; Anovazzi, G.; D'Silva, N.J.; Junior, C.R. HNSCC subverts PBMCs to secrete soluble products that promote tumor cell proliferation. Oncotarget 2017, 8, 60860-60874. [CrossRef] [PubMed]

49. White, R.A.; Malkoski, S.P.; Wang, X.-J. TGF $\beta$ signaling in head and neck squamous cell carcinoma. Oncogene 2010, $29,5437-5446$. [CrossRef]

50. Bornstein, S.; Schmidt, M.; Choonoo, G.; Levin, T.; Gray, J.; Thomas, C.R., Jr.; Wong, M.; McWeeney, S. IL-10 and integrin signaling pathways are associated with head and neck cancer progression. BMC Genom. 2016, 17, 1-9. [CrossRef] [PubMed]

51. Duffy, S.A.; Taylor, J.M.G.; Terrell, J.E.; Islam, M.; Li, Y.; Fowler, K.E.; Wolf, G.T.; Teknos, T.N. Interleukin-6 predicts recurrence and survival among head and neck cancer patients. Cancer 2008, 113, 750-757. [CrossRef] [PubMed]

52. Tsai, M.-S.; Chen, W.-C.; Lu, C.-H.; Chen, M.-F. The prognosis of head and neck squamous cell carcinoma related to immunosuppressive tumor microenvironment regulated by IL-6 signaling. Oral Oncol. 2019, 91, 47-55. [CrossRef] [PubMed]

53. Bergmann, C.; Strauss, L.; Zeidler, R.; Lang, S.; Whiteside, T.L. Expansion of Human T Regulatory Type 1 Cells in the Microenvironment of Cyclooxygenase 2 Overexpressing Head and Neck Squamous Cell Carcinoma. Cancer Res. 2007, 67, 8865-8873. [CrossRef] [PubMed] 
54. Camacho, M.; León, X.; Fernández-Figueras, M.-T.; Quer, M.; Vila, L. Prostaglandin E2pathway in head and neck squamous cell carcinoma. Head Neck 2008, 30, 1175-1181. [CrossRef]

55. Lang, S.; Tiwari, S.; Andratschke, M.; Loehr, I.; Lauffer, L.; Bergmann, C.; Mack, B.; Lebeau, A.; Moosmann, A.; Whiteside, T.L.; et al. Immune restoration in head and neck cancer patients after in vivo COX-2 inhibition. Cancer Immunol. Immunother. 2007, 56, 1645-1652. [CrossRef]

56. Gallo, O.; Franchi, A.; Magnelli, L.; Sardi, I.; Vannacci, A.; Boddit, V.; Chiarugi, V.; Masini, E. Cyclooxygenase-2 Pathway Correlates with VEGF Expression in Head and Neck Cancer. Implications for Tumor Angiogenesis and Metastasis. Neoplasia 2001, 3, 53-61. [CrossRef]

57. Kyzas, P.A.; Cunha, I.W.; Ioannidis, J.P. Prognostic Significance of Vascular Endothelial Growth Factor Immunohistochemical Expression in Head and Neck Squamous Cell Carcinoma: A Meta-Analysis. Clin. Cancer Res. 2005, 11, 1434-1440. [CrossRef] [PubMed]

58. Le, Q.-T.; Shi, G.; Cao, H.; Nelson, D.W.; Wang, Y.; Chen, E.Y.; Zhao, S.; Kong, C.; Richardson, D.; O’Byrne, K.J.; et al. Galectin-1: A Link Between Tumor Hypoxia and Tumor Immune Privilege. J. Clin. Oncol. 2005, 23, 8932-8941. [CrossRef]

59. Maybruck, B.T.; Pfannenstiel, L.W.; Diaz-Montero, M.; Gastman, B.R. Tumor-derived exosomes induce CD8+ T cell suppressors. J. Immunother. Cancer 2017, 5, 65. [CrossRef]

60. Nambiar, D.K.; Aguilera, T.; Cao, H.; Kwok, S.; Kong, C.; Bloomstein, J.; Wang, Z.; Rangan, V.S.; Jiang, D.; Von Eyben, R.; et al. Galectin-1-driven T cell exclusion in the tumor endothelium promotes immunotherapy resistance. J. Clin. Investig. 2019, 129, 5553-5567. [CrossRef] [PubMed]

61. Network, T.C.G.A. Comprehensive genomic characterization of head and neck squamous cell carcinomas. Nat. Cell Biol. 2015, 517, 576-582. [CrossRef]

62. Ogino, T.; Shigyo, H.; Ishii, H.; Katayama, A.; Miyokawa, N.; Harabuchi, Y.; Ferrone, S. HLA Class I Antigen Down-regulation in Primary Laryngeal Squamous Cell Carcinoma Lesions as a Poor Prognostic Marker. Cancer Res. 2006, 66, 9281-9289. [CrossRef]

63. López-Albaitero, A.; Nayak, J.V.; Ogino, T.; Machandia, A.; Gooding, W.; DeLeo, A.B.; Ferrone, S.; Ferris, R.L. Role of AntigenProcessing Machinery in the In Vitro Resistance of Squamous Cell Carcinoma of the Head and Neck Cells to Recognition by CTL. J. Immunol. 2006, 176, 3402-3409. [CrossRef] [PubMed]

64. Zhou, L.; Mudianto, T.; Ma, X.; Riley, R.; Uppaluri, R. Targeting EZH2 Enhances Antigen Presentation, Antitumor Immunity, and Circumvents Anti-PD-1 Resistance in Head and Neck Cancer. Clin. Cancer Res. 2019, 26, 290-300. [CrossRef]

65. Rotte, A.; Jin, J.; Lemaire, V. Mechanistic overview of immune checkpoints to support the rational design of their combinations in cancer immunotherapy. Ann. Oncol. 2018, 29, 71-83. [CrossRef]

66. Leach, D.R.; Krummel, M.F.; Allison, J.P. Enhancement of Antitumor Immunity by CTLA-4 Blockade. Science 1996, 271, 1734-1736. [CrossRef] [PubMed]

67. Yu, G.-T.; Bu, L.-L.; Zhao, Y.-Y.; Mao, L.; Deng, W.-W.; Wu, T.-F.; Zhang, W.-F.; Sun, Z.-J. CTLA4 blockade reduces immature myeloid cells in head and neck squamous cell carcinoma. OncoImmunology 2016, 5, e1151594. [CrossRef] [PubMed]

68. Wang, Z.; Wu, V.H.; Allevato, M.M.; Gilardi, M.; He, Y.; Callejas-Valera, J.L.; Vitale-Cross, L.; Martin, D.; Amornphimoltham, P.; McDermott, J.; et al. Syngeneic animal models of tobacco-associated oral cancer reveal the activity of in situ anti-CTLA-4. Nat. Commun. 2019, 10, 1-13. [CrossRef]

69. Jie, H.-B.; Schuler, P.J.; Lee, S.C.; Srivastava, R.M.; Argiris, A.; Ferrone, S.; Whiteside, T.L.; Ferris, R.L. CTLA-4+ Regulatory T Cells Increased in Cetuximab-Treated Head and Neck Cancer Patients Suppress NK Cell Cytotoxicity and Correlate with Poor Prognosis. Cancer Res. 2015, 75, 2200-2210. [CrossRef]

70. Gao, Y.; Nihira, N.T.; Bu, X.; Chu, C.; Zhang, J.; Kolodziejczyk, A.; Fan, Y.; Chan, N.T.; Ma, L.; Liu, J.; et al. Acetylation-dependent regulation of PD-L1 nuclear translocation dictates the efficacy of anti-PD-1 immunotherapy. Nat. Cell Biol. 2020, 22, 1-12. [CrossRef]

71. Dammeijer, F.; Van Gulijk, M.; Mulder, E.E.; Lukkes, M.; Klaase, L.; Bosch, T.V.D.; Van Nimwegen, M.; Lau, S.P.; Latupeirissa, K.; Schetters, S.; et al. The PD-1/PD-L1-Checkpoint Restrains T cell Immunity in Tumor-Draining Lymph Nodes. Cancer Cell 2020, 38, 685-700.e8. [CrossRef]

72. Karpathiou, G.; Casteillo, F.; Giroult, J.-B.; Forest, F.; Fournel, P.; Monaya, A.; Froudarakis, M.; Dumollard, J.M.; Prades, J.M.; Peoc' $\mathrm{H}, \mathrm{M}$. Prognostic impact of immune microenvironment in laryngeal and pharyngeal squamous cell carcinoma: Immune cell subtypes, immuno-suppressive pathways and clinicopathologic characteristics. Oncotarget 2016, 8, 19310-19322. [CrossRef] [PubMed]

73. Ock, C.-Y.; Kim, S.; Keam, B.; Kim, M.; Kim, T.M.; Kim, J.-H.; Jeon, Y.K.; Lee, J.-S.; Kwon, S.K.; Hah, J.H.; et al. PD-L1 expression is associated with epithelial-mesenchymal transition in head and neck squamous cell carcinoma. Oncotarget 2016, 7, 15901-15914. [CrossRef] [PubMed]

74. Concha-Benavente, F.; Srivastava, R.M.; Trivedi, S.; Lei, Y.; Chandran, U.R.; Seethala, R.R.; Freeman, G.J.; Ferris, R.L. Identification of the Cell-Intrinsic and -Extrinsic Pathways Downstream of EGFR and IFN $\gamma$ That Induce PD-L1 Expression in Head and Neck Cancer. Cancer Res. 2016, 76, 1031-1043. [CrossRef]

75. Badoual, C.; Hans, S.; Merillon, N.; Van Ryswick, C.; Ravel, P.; Benhamouda, N.; Levionnois, E.; Nizard, M.; Si-Mohamed, A.; Besnier, N.; et al. PD-1-Expressing Tumor-Infiltrating T Cells Are a Favorable Prognostic Biomarker in HPV-Associated Head and Neck Cancer. Cancer Res. 2012, 73, 128-138. [CrossRef] 
76. Theodoraki, M.-N.; Yerneni, S.S.; Hoffmann, T.K.; Gooding, W.E.; Whiteside, T.L. Clinical Significance of PD-L1+ Exosomes in Plasma of Head and Neck Cancer Patients. Clin. Cancer Res. 2018, 24, 896-905. [CrossRef] [PubMed]

77. Punt, S.; Thijssen, V.L.; Vrolijk, J.; De Kroon, C.D.; Gorter, A.; Jordanova, E.S. Galectin-1, -3 and -9 Expression and Clinical Significance in Squamous Cervical Cancer. PLoS ONE 2015, 10, e0129119. [CrossRef] [PubMed]

78. Workman, C.J.; Dugger, K.J.; Vignali, D.A.A. Cutting Edge: Molecular Analysis of the Negative Regulatory Function of Lymphocyte Activation Gene-3. J. Immunol. 2002, 169, 5392-5395. [CrossRef]

79. Liang, B.; Workman, C.; Lee, J.; Chew, C.; Dale, B.M.; Colonna, L.; Flores, M.; Li, N.; Schweighoffer, E.; Greenberg, S.; et al. Regulatory T Cells Inhibit Dendritic Cells by Lymphocyte Activation Gene-3 Engagement of MHC Class II. J. Immunol. 2008, 180, 5916-5926. [CrossRef]

80. Kouo, T.S.; Huang, L.; Pucsek, A.B.; Cao, M.; Solt, S.; Armstrong, T.D.; Jaffee, E.M. Galectin-3 Shapes Antitumor Immune Responses by Suppressing CD8+ T Cells via LAG-3 and Inhibiting Expansion of Plasmacytoid Dendritic Cells. Cancer Immunol. Res. 2015, 3, 412-423. [CrossRef] [PubMed]

81. Deng, W.-W.; Mao, L.; Yu, G.-T.; Bu, L.-L.; Ma, S.-R.; Liu, B.; Gutkind, J.S.; Kulkarni, A.B.; Zhang, W.-F.; Sun, Z.-J. LAG-3 confers poor prognosis and its blockade reshapes antitumor response in head and neck squamous cell carcinoma. OncoImmunology 2016, 5, e1239005. [CrossRef] [PubMed]

82. Somasundaram, A.; Cillo, A.R.; Lampenfeld, C.; Oliveri, L.; Velez, M.A.; Joyce, S.; Calderon, M.J.; Dadey, R.; Rajasundaram, D.; Normolle, D.P.; et al. Systemic Immune Dysfunction in Cancer Patients Driven by IL6 and IL8 Induction of an Inhibitory Receptor Module in Peripheral CD8 ${ }^{+}$T Cells. bioRxiv 2020. [CrossRef]

83. Liu, J.-F.; Wu, L.; Yang, L.-L.; Deng, W.-W.; Mao, L.; Wu, H.; Zhang, W.-F.; Sun, Z.-J. Blockade of TIM3 relieves immunosuppression through reducing regulatory $\mathrm{T}$ cells in head and neck cancer. J. Exp. Clin. Cancer Res. 2018, 37, 1-8. [CrossRef]

84. Liu, J.-F.; Ma, S.-R.; Mao, L.; Bu, L.-L.; Yu, G.-T.; Li, Y.-C.; Huang, C.-F.; Deng, W.-W.; Kulkarni, A.B.; Zhang, W.-F.; et al. T-cell immunoglobulin mucin 3 blockade drives an antitumor immune response in head and neck cancer. Mol. Oncol. 2017, 11, 235-247. [CrossRef]

85. Wu, L.; Mao, L.; Liu, J.-F.; Chen, L.; Yu, G.-T.; Yang, L.-L.; Wu, H.; Bu, L.-L.; Kulkarni, A.B.; Zhang, W.-F.; et al. Blockade of TIGIT/CD155 Signaling Reverses T-cell Exhaustion and Enhances Antitumor Capability in Head and Neck Squamous Cell Carcinoma. Cancer Immunol. Res. 2019, 7, 1700-1713. [CrossRef]

86. Gameiro, S.F.; Ghasemi, F.; Barrett, J.W.; Koropatnick, J.; Nichols, A.C.; Mymryk, J.S.; Vareki, S.M. Treatment-naïve HPV head and neck cancers display a T-cell-inflamed phenotype distinct from their HPV counterparts that has implications for immunotherapy. OncoImmunology 2018, 7, e1498439. [CrossRef]

87. Seiwert, T.Y.; Burtness, B.; Mehra, R.; Weiss, J.; Berger, R.; Eder, J.P.; Heath, K.; McClanahan, T.; Lunceford, J.; Gause, C.; et al. Safety and clinical activity of pembrolizumab for treatment of recurrent or metastatic squamous cell carcinoma of the head and neck (KEYNOTE-012): An open-label, multicentre, phase 1b trial. Lancet Oncol. 2016, 17, 956-965. [CrossRef]

88. Chow, L.Q.; Haddad, R.; Gupta, S.; Mahipal, A.; Mehra, R.; Tahara, M.; Berger, R.; Eder, J.P.; Burtness, B.; Lee, S.-H.; et al. Antitumor Activity of Pembrolizumab in Biomarker-Unselected Patients With Recurrent and/or Metastatic Head and Neck Squamous Cell Carcinoma: Results From the Phase Ib KEYNOTE-012 Expansion Cohort. J. Clin. Oncol. 2016, 34, $3838-3845$. [CrossRef]

89. Bauml, J.; Seiwert, T.Y.; Pfister, D.G.; Worden, F.; Liu, S.V.; Gilbert, J.; Saba, N.F.; Weiss, J.; Wirth, L.; Sukari, A.; et al. Pembrolizumab for Platinum- and Cetuximab-Refractory Head and Neck Cancer: Results From a Single-Arm, Phase II Study. J. Clin. Oncol. 2017, 35, 1542-1549. [CrossRef] [PubMed]

90. Ferris, R.L.; Blumenschein, G., Jr.; Fayette, J.; Guigay, J.; Colevas, A.D.; Licitra, L.; Harrington, K.; Kasper, S.; Vokes, E.E.; Even, C.; et al. Nivolumab for Recurrent Squamous-Cell Carcinoma of the Head and Neck. N. Engl. J. Med. 2016, 375, $1856-1867$. [CrossRef] [PubMed]

91. Cohen, E.E.W.; Soulières, D.; Le Tourneau, C.; Dinis, J.; Licitra, L.; Ahn, M.-J.; Soria, A.; Machiels, J.-P.; Mach, N.; Mehra, R.; et al. Pembrolizumab versus methotrexate, docetaxel, or cetuximab for recurrent or metastatic head-and-neck squamous cell carcinoma (KEYNOTE-040): A randomised, open-label, phase 3 study. Lancet 2019, 393, 156-167. [CrossRef]

92. Burtness, B.; Harrington, K.J.; Greil, R.; Soulières, D.; Tahara, M.; de Castro, G.; Psyrri, A.; Basté, N.; Neupane, P.; Bratland, Å.; et al. Pembrolizumab alone or with chemotherapy versus cetuximab with chemotherapy for recurrent or metastatic squamous cell carcinoma of the head and neck (KEYNOTE-048): A randomised, open-label, phase 3 study. Lancet 2019, 394, 1915-1928. [CrossRef]

93. Yu, Y.; Lee, N.Y. JAVELIN Head and Neck 100: A Phase III trial of avelumab and chemoradiation for locally advanced head and neck cancer. Futur. Oncol. 2019, 15, 687-694. [CrossRef]

94. Pardoll, D.M. The blockade of immune checkpoints in cancer immunotherapy. Nat. Rev. Cancer 2012, 12, 252-264. [CrossRef] [PubMed]

95. Callahan, M.K.; Wolchok, J.D.; Allison, J.P. Anti-CTLA-4 Antibody Therapy: Immune Monitoring During Clinical Development of a Novel Immunotherapy. Semin. Oncol. 2010, 37, 473-484. [CrossRef] [PubMed]

96. Ferris, R.; Haddad, R.; Even, C.; Tahara, M.; Dvorkin, M.; Ciuleanu, T.; Clement, P.; Mesia, R.; Kutukova, S.; Zholudeva, L.; et al. Durvalumab with or without tremelimumab in patients with recurrent or metastatic head and neck squamous cell carcinoma: EAGLE, a randomized, open-label phase III study. Ann. Oncol. 2020, 31, 942-950. [CrossRef] 
97. Klinghammer, K.F.; Gauler, T.C.; Stromberger, C.; Kofla, G.; De Wit, M.; Gollrad, J.; Rauer, I.; Martus, P.; Tinhofer, I.; Budach, V.; et al. DURTRERAD: A phase II open-label study evaluating feasibility and efficacy of durvalumab (D) and durvalumab and tremelimumab (DT) in combination with radiotherapy (RT) in non-resectable locally advanced HPV-negative HNSCC-Results of the preplanned feasibility interim analysis. J. Clin. Oncol. 2020, 38, 6574. [CrossRef]

98. Machiels, J.-P.; Tao, Y.; Burtness, B.; Tahara, M.; Licitra, L.; Rischin, D.; Waldron, J.; Simon, C.; Gregoire, V.; Harrington, K.; et al. Pembrolizumab given concomitantly with chemoradiation and as maintenance therapy for locally advanced head and neck squamous cell carcinoma: KEYNOTE-412. Futur. Oncol. 2020, 16, 1235-1243. [CrossRef]

99. Massarelli, E.; William, W.; Johnson, F.; Kies, M.; Ferrarotto, R.; Guo, M.; Feng, L.; Lee, J.J.; Tran, H.; Kim, Y.U.; et al. Combining Immune Checkpoint Blockade and Tumor-Specific Vaccine for Patients With Incurable Human Papillomavirus 16-Related Cancer. JAMA Oncol. 2019, 5, 67-73. [CrossRef] [PubMed]

100. Le Tourneau, C.; Delord, J.-P.; Cassier, P.; Loirat, D.; Tavernaro, A.; Bastien, B.; Bendjama, K. Phase Ib/II trial of TG4001 (Tipapkinogene sovacivec), a therapeutic HPV-vaccine, and Avelumab in patients with recurrent/metastatic (R/M) HPV-16+ cancers. Ann. Oncol. 2019, 30, v494-v495. [CrossRef]

101. Stafford, M.; Kaczmar, J. The neoadjuvant paradigm reinvigorated: A review of pre-surgical immunotherapy in HNSCC. Cancers Head Neck 2020, 5, 4-9. [CrossRef]

102. Uppaluri, R.; Campbell, K.M.; Egloff, A.M.; Zolkind, P.; Skidmore, Z.L.; Nussenbaum, B.; Paniello, R.C.; Rich, J.T.; Jackson, R.; Pipkorn, P.; et al. Neoadjuvant and Adjuvant Pembrolizumab in Resectable Locally Advanced, Human Papillomavirus-Unrelated Head and Neck Cancer: A Multicenter, Phase 2 Trial. Clin. Cancer Res. 2020, 26, 5140-5152. [CrossRef] [PubMed]

103. Ferris, R.; Gonçalves, A.; Baxi, S.; Martens, U.; Gauthier, H.; Langenberg, M.; Spanos, W.; Leidner, R.; Kang, H.; Russell, J.; et al. An open-label, multicohort, phase 1/2 study in patients with virus-associated cancers (CheckMate 358): Safety and efficacy of neoadjuvant nivolumab in squamous cell carcinoma of the head and neck (SCCHN). Ann. Oncol. 2017, 28, v628-v629. [CrossRef]

104. Wise-Draper, T.M.; Old, M.O.; Worden, F.P.; O’Brien, P.E.; Cohen, E.E.; Dunlap, N.; Mierzwa, M.L.; Casper, K.; Palackdharry, S.; Hinrichs, B.; et al. Phase II multi-site investigation of neoadjuvant pembrolizumab and adjuvant concurrent radiation and pembrolizumab with or without cisplatin in resected head and neck squamous cell carcinoma. J. Clin. Oncol. 2018, $36,6017$. [CrossRef]

105. Wong, D.J.; Fayette, J.; Guo, Y.; Kowgier, M.; Cohen, E.; Nin, R.M.; Dechaphunkul, A.; Prabhash, K.; Geiger, J.; Bishnoi, S.; et al. Abstract CT123: IMvoke010: Randomized Phase III study of atezolizumab as adjuvant monotherapy after definitive therapy of squamous cell carcinoma of the head and neck (SCCHN). In Clinical Trials; American Association for Cancer Research (AACR): Philadelphia, PA, USA, 2019.

106. Busch, C.-J.; Muenscher, A.; Betz, C.S.; Dogan, V.; Schafhausen, P.; Bokemeyer, C.; Binder, M. Multicenter randomized controlled phase III study of nivolumab alone or in combination with ipilimumab as immunotherapy vs standard follow-up in surgical resectable HNSCC after adjuvant therapy. J. Clin. Oncol. 2019, 37, TPS6095. [CrossRef]

107. Cohen, E.E.W.; Bell, R.B.; Bifulco, C.B.; Burtness, B.; Gillison, M.L.; Harrington, K.J.; Le, Q.-T.; Lee, N.Y.; Leidner, R.; Lewis, R.L.; et al. The Society for Immunotherapy of Cancer consensus statement on immunotherapy for the treatment of squamous cell carcinoma of the head and neck (HNSCC). J. Immunother. Cancer 2019, 7, 184. [CrossRef]

108. Hegde, P.S.; Chen, D.S. Top 10 Challenges in Cancer Immunotherapy. Immunity 2020, 52, 17-35. [CrossRef] [PubMed]

109. Mckean, W.B.; Moser, J.C.; Rimm, D.; Hu-Lieskovan, S. Biomarkers in Precision Cancer Immunotherapy: Promise and Challenges. Am. Soc. Clin. Oncol. Educ. Book 2020, 40, e275-e291. [CrossRef] [PubMed]

110. Le, D.T.; Durham, J.N.; Smith, K.N.; Wang, H.; Bartlett, B.R.; Aulakh, L.K.; Lu, S.; Kemberling, H.; Wilt, C.; Luber, B.S.; et al. Mismatch repair deficiency predicts response of solid tumors to PD-1 blockade. Science 2017, 357, 409-413. [CrossRef]

111. Havel, J.J.; Chowell, D.; Chan, T.A. The evolving landscape of biomarkers for checkpoint inhibitor immunotherapy. Nat. Rev. Cancer 2019, 19, 133-150. [CrossRef]

112. Samstein, R.M.; Lee, C.-H.; Shoushtari, A.N.; Hellmann, M.D.; Shen, R.; Janjigian, Y.Y.; Barron, D.A.; Zehir, A.; Jordan, E.J.; Omuro, A.; et al. Tumor mutational load predicts survival after immunotherapy across multiple cancer types. Nat. Genet. 2019, 51, 202-206. [CrossRef] [PubMed]

113. Cristescu, R.; Mogg, R.; Ayers, M.; Albright, A.; Murphy, E.; Yearley, J.; Sher, X.; Liu, X.Q.; Lu, H.; Nebozhyn, M.; et al. Pan-tumor genomic biomarkers for PD-1 checkpoint blockade-based immunotherapy. Science 2018, 362, eaar3593. [CrossRef] [PubMed]

114. De La Iglesia, J.V.; Slebos, R.J.; Martin-Gomez, L.; Wang, X.; Teer, J.K.; Tan, A.C.; Gerke, T.A.; Aden-Buie, G.; Van Veen, T.; Masannat, J.; et al. Effects of Tobacco Smoking on the Tumor Immune Microenvironment in Head and Neck Squamous Cell Carcinoma. Clin. Cancer Res. 2020, 26, 1474-1485. [CrossRef] [PubMed]

115. Desrichard, A.; Kuo, F.; Chowell, D.; Lee, K.-W.; Riaz, N.; Wong, R.J.; A Chan, T.; Morris, L.G.T. Tobacco Smoking-Associated Alterations in the Immune Microenvironment of Squamous Cell Carcinomas. J. Natl. Cancer Inst. 2018, 110, 1386-1392. [CrossRef] [PubMed]

116. Rizvi, N.A.; Hellmann, M.D.; Snyder, A.; Kvistborg, P.; Makarov, V.; Havel, J.J.; Lee, W.; Yuan, J.; Wong, P.; Ho, T.S.; et al. Mutational landscape determines sensitivity to PD-1 blockade in non-small cell lung cancer. Science 2015, 348, 124-128. [CrossRef]

117. Kreimer, A.R.; Clifford, G.M.; Boyle, P.; Franceschi, S. Human Papillomavirus Types in Head and Neck Squamous Cell Carcinomas Worldwide: A Systematic Review. Cancer Epidemiol. Biomark. Prev. 2005, 14, 467-475. [CrossRef] [PubMed]

118. Davis, A.A.; Patel, V.G. The role of PD-L1 expression as a predictive biomarker: An analysis of all US Food and Drug Administration (FDA) approvals of immune checkpoint inhibitors. J. Immunother. Cancer 2019, 7, 1-8. [CrossRef] 
119. Rasmussen, J.H.; Lelkaitis, G.; Håkansson, K.; Vogelius, I.R.; Johannesen, H.H.; Fischer, B.M.; Bentzen, S.M.; Specht, L.; Kristensen, C.A.; Von Buchwald, C.; et al. Intratumor heterogeneity of PD-L1 expression in head and neck squamous cell carcinoma. Br. J. Cancer 2019, 120, 1003-1006. [CrossRef]

120. Hong, L.; Negrao, M.V.; Dibaj, S.S.; Chen, R.; Reuben, A.; Bohac, J.M.; Liu, X.; Skoulidis, F.; Gay, C.M.; Cascone, T.; et al. Programmed Death-Ligand 1 Heterogeneity and Its Impact on Benefit From Immune Checkpoint Inhibitors in NSCLC. J. Thorac. Oncol. 2020, 15, 1449-1459. [CrossRef]

121. De Ruiter, E.J.; Mulder, F.J.; Koomen, B.M.; Speel, E.-J.; Hout, M.F.C.M.V.D.; De Roest, R.H.; Bloemena, E.; Devriese, L.A.; Willems, S.M. Comparison of three PD-L1 immunohistochemical assays in head and neck squamous cell carcinoma (HNSCC). Mod. Pathol. 2020, 1-8. [CrossRef]

122. Daassi, D.; Mahoney, K.M.; Freeman, G.J. The importance of exosomal PDL1 in tumour immune evasion. Nat. Rev. Immunol. 2020, 20, 209-215. [CrossRef]

123. Theodoraki, M.-N.; Yerneni, S.; Gooding, W.E.; Ohr, J.; Clump, D.A.; Bauman, J.E.; Ferris, R.L.; Whiteside, T.L. Circulating exosomes measure responses to therapy in head and neck cancer patients treated with cetuximab, ipilimumab, and IMRT OncoImmunology 2019, 8, e1593805. [CrossRef]

124. Ayers, M.; Lunceford, J.; Nebozhyn, M.; Murphy, E.; Loboda, A.; Kaufman, D.R.; Albright, A.; Cheng, J.D.; Kang, S.P.; Shankaran, V.; et al. IFN- $\gamma$-related mRNA profile predicts clinical response to PD-1 blockade. J. Clin. Investig. 2017, 127, 2930-2940. [CrossRef] [PubMed]

125. Chen, Y.-P.; Wang, Y.-Q.; Lv, J.-W.; Li, Y.-Q.; Chua, M.; Le, Q.-T.; Lee, N.; Colevas, A.D.; Seiwert, T.; Hayes, D.; et al. Identification and validation of novel microenvironment-based immune molecular subgroups of head and neck squamous cell carcinoma: Implications for immunotherapy. Ann. Oncol. 2019, 30, 68-75. [CrossRef]

126. Ren, X.; Kang, B.; Zhang, Z. Understanding tumor ecosystems by single-cell sequencing: Promises and limitations. Genome Biol. 2018, 19, 211. [CrossRef]

127. Puram, S.V.; Tirosh, I.; Parikh, A.S.; Patel, A.P.; Yizhak, K.; Gillespie, S.; Rodman, C.; Luo, C.L.; Mroz, E.A.; Emerick, K.S.; et al. Single-Cell Transcriptomic Analysis of Primary and Metastatic Tumor Ecosystems in Head and Neck Cancer. Cell 2017, 171, 1611-1624.e24. [CrossRef]

128. Börnigen, D.; Ren, B.; Pickard, R.; Li, J.; Ozer, E.; Hartmann, E.M.; Xiao, W.; Tickle, T.; Rider, J.; Gevers, D.; et al. Alterations in oral bacterial communities are associated with risk factors for oral and oropharyngeal cancer. Sci. Rep. 2017, 7, 1-13. [CrossRef] [PubMed]

129. Hayes, R.B.; Ahn, J.; Fan, X.; Peters, B.A.; Ma, Y.; Yang, L.; Agalliu, I.; Burk, R.D.; Ganly, I.; Purdue, M.P.; et al. Association of Oral Microbiome With Risk for Incident Head and Neck Squamous Cell Cancer. JAMA Oncol. 2018, 4, 358-365. [CrossRef] [PubMed]

130. Garrett, W.S. Cancer and the microbiota. Science 2015, 348, 80-86. [CrossRef]

131. Routy, B.; Gopalakrishnan, V.; Daillère, R.; Zitvogel, L.; Wargo, J.A.; Kroemer, G. The gut microbiota influences anticancer immunosurveillance and general health. Nat. Rev. Clin. Oncol. 2018, 15, 382-396. [CrossRef] [PubMed]

132. Gopalakrishnan, V.; Spencer, C.N.; Nezi, L.; Reuben, A.; Andrews, M.C.; Karpinets, T.V.; Prieto, P.A.; Vicente, D.; Hoffman, K.; Wei, S.C.; et al. Gut microbiome modulates response to anti-PD-1 immunotherapy in melanoma patients. Science 2018, 359, 97-103. [CrossRef]

133. Zheng, Y.; Wang, T.; Tu, X.; Huang, Y.; Zhang, H.; Tan, D.; Jiang, W.; Cai, S.; Zhao, P.; Song, R.; et al. Gut microbiome affects the response to anti-PD-1 immunotherapy in patients with hepatocellular carcinoma. J. Immunother. Cancer 2019, 7, 193. [CrossRef] [PubMed]

134. Wang, S.; He, Z.; Wang, X.; Li, H.; Liu, X.-S. Antigen presentation and tumor immunogenicity in cancer immunotherapy response prediction. eLife 2019,8, 8. [CrossRef]

135. Charoentong, P.; Finotello, F.; Angelova, M.; Mayer, C.; Efremova, M.; Rieder, D.; Hackl, H.; Trajanoski, Z. Pan-cancer Immunogenomic Analyses Reveal Genotype-Immunophenotype Relationships and Predictors of Response to Checkpoint Blockade. Cell Rep. 2017, 18, 248-262. [CrossRef]

136. Lu, S.; Stein, J.E.; Rimm, D.L.; Wang, D.W.; Bell, J.M.; Johnson, D.B.; Sosman, J.A.; Schalper, K.A.; Anders, R.A.; Wang, H.; et al. Comparison of Biomarker Modalities for Predicting Response to PD-1/PD-L1 Checkpoint Blockade. JAMA Oncol. 2019, 5, 1195-1204. [CrossRef]

137. Van Schalkwyk, M.C.I.; Papa, S.E.; Jeannon, J.-P.; Urbano, T.G.; Spicer, J.F.; Maher, J. Design of a Phase I Clinical Trial to Evaluate Intratumoral Delivery of ErbB-Targeted Chimeric Antigen Receptor T-Cells in Locally Advanced or Recurrent Head and Neck Cancer. Hum. Gene Ther. Clin. Dev. 2013, 24, 134-142. [CrossRef] [PubMed]

138. June, C.H.; O'Connor, R.S.; Kawalekar, O.U.; Ghassemi, S.; Milone, M.C. CAR T cell immunotherapy for human cancer. Science 2018, 359, 1361-1365. [CrossRef] [PubMed]

139. Mei, Z.; Zhang, K.; Lam, A.K.; Huang, J.; Qiu, F.; Qiao, B.; Zhang, Y. MUC1 as a target for CAR-T therapy in head and neck squamous cell carinoma. Cancer Med. 2019, 9, 640-652. [CrossRef] [PubMed] 